\title{
Biophysical Assessment of a Reciprocal Vertical Force System on Posterior Teeth in Normal Functional Occlusion
}

Gerald Jeffry

Loyola University Chicago

Follow this and additional works at: https://ecommons.luc.edu/luc_theses

Part of the Medicine and Health Sciences Commons

\section{Recommended Citation}

Jeffry, Gerald, "Biophysical Assessment of a Reciprocal Vertical Force System on Posterior Teeth in Normal Functional Occlusion" (1965). Master's Theses. 1985.

https://ecommons.luc.edu/luc_theses/1985

This Thesis is brought to you for free and open access by the Theses and Dissertations at Loyola eCommons. It has been accepted for inclusion in Master's Theses by an authorized administrator of Loyola eCommons. For more information, please contact ecommons@luc.edu.

Copyright @ 1965 Gerald Jeffry 


\title{
BIOPNYSICAL ASSESSMENT OF A RECIPROCAL VERTICAL MORCE SYSTEM ON POSTERIOR TEETH IN NORMAL FUNCTIONAL OCCLUSION
}

\author{
BY \\ GERALD J. JEFERY
}

A Thesis Submitted to the Faculty of the Graduate school of Loyola Uniworaty in Partial Fulfulmant o:

the Requirements for the Dorree of

Master of Sclence

JNE

1965

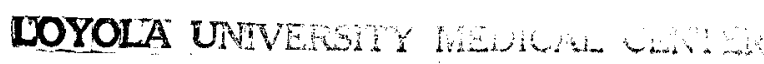




\section{LIF}

Gerald J. Jefky was born in Cakland, Callornia, Decomber 6 ,

1937. He was graduated rom Bellarmine College Preparatory, San Jose, Calliomia in 1955. He attendod Santa Clara Univeraity for one yoar and then the University of San Francisco for two years. In June, 1963 he graduated from Loyola University School of Dentiatry. Chicago, Ininois, with the degree of Doctor of Dental Surgery.

The author began gruduate atudieg in the Dapartment of Oral Biology of Loyola Univeraity, Chicago, in june 1963. 


\section{ACKNOWLEDGMENTS}

I would like to extend my sincere appreciation to my Professo: of Orthodontics, Joseph R. Jaratak, D. D. S. Ph. D. , tor his untirtig aforts both as a teacher and an advisor for this rescarch.

To James A. Fizcell, B.S. in E. R., for his astute lnaight into the pro lems of blophysics and its relationglip to orthodontics and in particular to this rescarch.

To Joseph Gowgiel, D.D.S. , Ph. D., I am gratetul for his helpit advice and assigtance in preparing and evaluating the histologic auctions.

I wish to extend my gincere gratitude to all my teachers and colleagues, both past and present, sor tholz inspiration, encourayoment, and ollowship. I would particularly like to thank $\mathrm{Dr}$. Dale Kostiwa for his patience, understanding, and Irtendahp in working together in a parallel animal experiment.

To the Loyola-jaratak Orthodontic Foundation, which provided Inancial asgistance for matertals and to prankin Boulevard Hosital where the rosearch animals were colonizod.

My thanks soes to Bartara Furmaniak for har help in the 
clorical preparation of this thesis.

It was with the love and gudance of my parents that I was

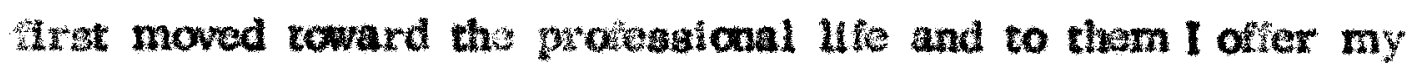
doepest gratitude. To my inmediate amily I offer my thanks for their bolp, love, and undarstanding without which this work would not have been postible. 


\section{TABLE OF CONT $\mathrm{NTS}$}

CHAPTER

PAGE

1. INTRODICTION AND STATEMENT OF TH: PROBLEM

A. Introductory kmarks. ................. 1

B. Statenen o the Prollen .............., 2

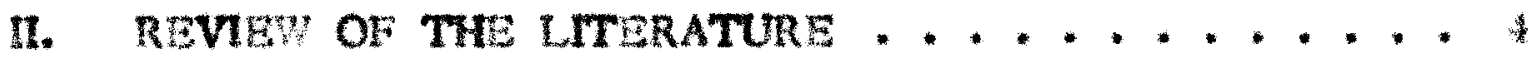

III. METHODS AND MATSRIALS:

A. Animal Care and Pooting. . . ......., ....,

B. Animal Handling and Anesthoti ation ........, 15

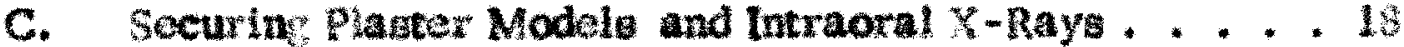

D. Selecting the Teath to we Moved Orthodantically . . . . 9

E. Dabigning Method to Mcasure Tooth Movement . . . . 20

F. Regiatration Indrument for Transior Unit Orientatioa. , 21

C. Tooth Mcasurin Instrument . . . . . . . . . . 2

H. Trating tha Precision of Measurement. . . . . . . 27

1. Determination o the Force Magnitude. . . . . . , 39

J. Degignin and Aralyang the Foree Syatem .......

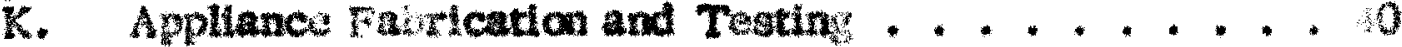

L. Comentation and Activation of the Appllance. . . . . . 1

M. Spectications o the Rubber Base Imprssaton Material and the Die Stone ....................

N. Sacridcing the Animala and Proparin Tisgtes by

Pertusion .......................

o. Matologle proparation. .............. 50

IV. FINDNGS:

A. Presentadion of Data ................ 2

B. Analyat or Variance lom the Exparimentally

Moved Touth. ................... 7

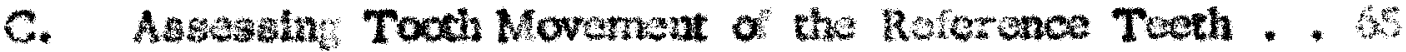

D. Tiasue Chasyes Caused by an Expomimental Extrusive

Force *..................... B7

E. Tigate Chunos Intuoncod an Experimantal

Intrusive Force. . . . . . . ..........70

F. Tisoue Changs Around the Raterence Teeth , , . .74 
CUATTER

V. DSCUssion ,......................81

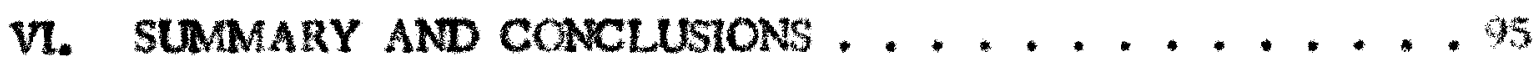
VI. BLBLIOCRARHY.......................... 99 


\section{LIST OF FIGUREs}

FIGURE

PACE

1. Monkey study Models. . . . . . . . . . . . . 20

2. A. Transter Unit and Transfer Unit tmpression . . . 22

B. Transter Unit Mounted in Carrier .........22

3. Reglatration Inatrument for Transer Unit Orientation . . . 24

^. A. Instrument to Measure Occlusal-Gingtival and Buceal-Lingual Took Movemants. ......... 25

B. Styll of the Dal Gauge ..............25

3. Normal Distributions or the Sources of Buperimental Error and Dupllcato Msasurements .......... 30

6. Force System Dasrama ................ 35

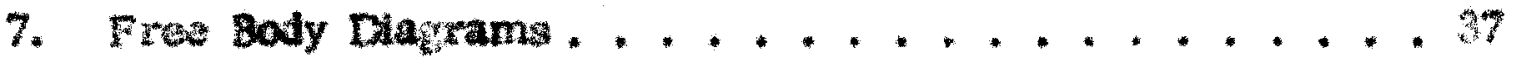

3. A. Instrumetat to Caleulate Load-Dehection Characteristics I1 B. Keyed Monkey Working Model . . . . . . . . . U

9. Dimensiona of Apliances in Millimeters. ........

10. Lad-Deflectica Curve of Applianeos. . . . . . . . . is

11. The Maxillary Right Slde and the Activated Helleal Loop Appllancet * The Maxillary Lett Reference Sido . . . . . it

12. The Mitten-Like Restraining Gloves, ............

13. Movenents of the Teeth in an Ccclusal-Gingival Diroction on the Experimeatal side. . . . . . . . . . . . B

14. Movone ita of the Toth in a Buccal-Lingual Direction an the Experimontal slde. .............. 
FIOURE

15. A. Right Side - Occlusal-Gingival Dimonaion Intraction Batween Animals and Teoth. . . . . . . 60

B. Right Side - Occluad-Gingival Dimengion

Interactions Botwoon Toth and Bxaminations. . . . . 60

16. A. Right side - Buccal-Lingual Dimansion

Interaction Betwoen Animale and Toeth. . . . . . , 64

B. Right Side - Buceal Lingual Dimenglon

Interaction Between Toeth and Eraminations . . . . . 6.

17. Diagrammatic Representation of Tpping in a BuccalLingual Dimenston. . . . . . . ............ 69

13. Experimentally ructruded Toath, Sagrtal Section . . . . . 71

19. Eperimental Tecth, Transvorse Section, . . . . . . . . 72

20. Exporimentally Int todod Took, Transwerse Sections . . . . 73

21. Bxperimentally Intruded Toch, Sagital Section. . . . . . 75

22. Experimental Toch, Tranevoree Soctions . . . . ... 76

23. Bxperimontally intudod Toch, Sagittal soction ..... * 77

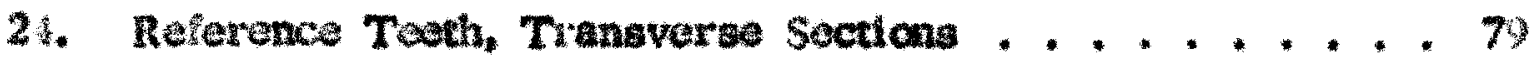

25. Reforence Terth, Sagitual Section . ............. Bo 


\section{LIST OF TABL.ES}

TABLE

1. Analysis of Variance sor the Preciaton o

Measurements Test ..............31

II. Sample Data Shoot .................

III. Sample Data shoet ................ 5 s

IV. Analysts or Variance Taule

Right Side - Ocelusal-Gingival Dimensica . . . ..... $\$ 8$

V. Analysis of Variance Table

Right Side - Buccal-Lingual Dimunaion . . . . . . 62

vi. Taule of Difrerences ................66 


\section{CHAPTER I}

\section{INTRODUCTION AND STATEMENT OF THE PROBLEM}

\section{A. Introductory Remarke:}

Moving tecth with orthodontic applances is a biophysical phenomenon involving both biologic and physical slements. The Woloyic elements are the cementum on the surface of the tooth roots, the various cellular components in the periodontal ligament, the blood and nerve supply, and the cellular structure of the alveolar kone. The physical elements in the process are the orthodontic appliances and the forces derived from them. The teeth act as mechanical levers tranamitting forces to the dentoalveoloperlodcntal anvironment.

Histologic studies in orthodontics have shown that tooth movement is made possible by bone resorption and bone formation of the alveolar tone surrounding the teeth. The processes of bone resorption and hone formation are gtimulated when forces applied to the crowns of the teeth cause preseures and tensions in the periodontal environment. It has boen demonstrated clinically and experimentally that there is a range of optinum torces which can cause physiologic tooth movement to 
occur at an increased rate.

Instuments have beon designod to derive load-dellection curves and to measure force magnitudes of orthodontic appliances. Orthodontic appliances have had an interesting evolution starting with crude. uxwieldy devices and riaing to andytically dealgnod, precision mnde mechines. The literature reveals that the historic evolution of orthodontic appliances and the study of their reaction on the teeth and their periodontal enviranment has resulted from the untiring eforts of a seat many Investigators woth in regearch and in clinical practice. Today"s orthodontic rosearch should in no way be considered as an attempt to disqualily earlier Investigators or thelr indings. Instaad, the modern researcher should view ary proposed study in its true perapective; an attempt to define, clarisy, and possibly improve on old basic premiges and methods so caratily established by the ploneers of arthodontics.

3. Statement of the Problema

This atudy ig destgned to cvaluste the hophysical Influence of a

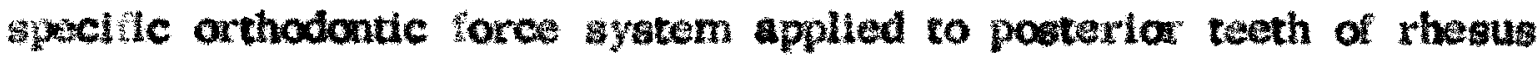
monkeys. Past studies in this area of assessment of toch movements 
have been mostly histologic. Although force systems were employed, thei true torcs magnitudes, couples, and moments were not clearly descrlbed, analyzed, and discussed. In this study, a predetermined torce system with calculated force magnitudes and directiona will be appliad to posterior teoth in their normal biologic environment of a thosts monkey. The amount and direction of tooth movement will be measured physically and will be determined histologically by the changes in the dentcalveoloperiodontal environment. 


\section{CHAPTER II}

REVIEW OF THE LITERATURE

The Irst histologic study of orthodontically moved teeth was done by Sandatedt (1901). He placed orthodontic appliances on the incisors oi dogs and moved these teeth labially or lingually. Histologic sections of the periodontal environment showed osteoclasts and bone resorption on the side of pressure and osteoblasts and bone formation on the side of tension.

Oppenheim (1909) performed a similar study on the incisor teeth of a primate (baboon). He used arch wires anchored to molar teath to tip. extrude, or intrude incisor teeth. He stated that whenever a tooth is pulled. new bone is formed on the tension side of the periodontal membrane. The new bone is arranged in the direction o the pulling force. Whenever pressure is exerted upon the alveolus, bone is resorbed, thus creating apace into which the tooth can move. Neither Sandatedk nor Oppenhelm quantitatively defined the orces they used in their experiments. They merely stated them as being light, medium, or heavy torces. Undermining resorption was described by both men as a phenomenon occurring when heavy 
forces were applied to tecth. Heavy forces caused compression of the periodontal membrans on the pressure side so that the blood supply was completely restricted over a localized area of bone, causing necroals of the bone and periodontal membrane. Hence the resorption o. bone canno take place rom the peridental aide of the lamina dura, but muat occur from behind and trom either side of the necrosed area. Undermining resorption continued until all necrodc tissue was removed, at which time the tooth could move rapldy into the space created.

Schwart (1932) was the hrat to apply known force magnitudes to tip premolare of dogs' teeth. He otudied histologically the effects of vartous continuous lorces and concluded that 20-26 grams per one square centimeter of root surface can bring about tooth movement without damage to the periodontal tissues. He gave little experimental evidence to fustify these specilic values.

Johnson, Appleton, and Rittershofer (1925) applied the lablolingual appliance on the teeth of two Macaque rhesus monkeys. The appliances remained on the teeth of one animal for twenty-six days and on the other animal for torty daye. The appliance uged generated a force o. 
two ounces in a lingual direction upon one maxillary incisor tooth. They reported the experiment demonstrated resorption and delormation of the rook at the apex.

In 1931, Marahall placed bands on monkey's central incisors and irst permanent molar and using a .030" round labial arch wire, claimed be intruded one incisor while extruding the other. He observed, histologically, that the extruded central incisor moved outward ir om the alveolus. This pulling effect gave rise to a proliteration of the Lone on the alveolar crests and the sot tissue accommodated accordingly. The central Incisor which was intruded showed, histologically, a large area of apical andorption with the preaence of an inflammatory reaction.

After a series of experiments where orthodontic forces wer. applied to the teeth o dogs and man. Stuteville (1937) verliled the changes that take place in the teeth and their supporting structures. He howed histologically that necrotic areas of the peridental morrbiane will heal, that resorted areas of the tooth will be repaired by secondary cementum, and that irritated gum tissue will heal. Stuteville reports that the position of root resorption depends on the type of tooth 
novements and the character of the applied orce. In a simple tipping movement by an auxiliary apring, the primary resorbed areas are at the alveolar crest on the pressure side and on the opposite side of the apical surface of the roc. Secondary resorption is produced on the rock surface in the areas diametrically opposite to the area of primary regorption. Secondary resorption regults from tooch Jigring that is caused by the forces of the inclined planes during mastication.

Reitan, in 1947 , reported on an experiment which investigated the changes taking place in the supporting tissue of teeth which were moved bodily with a continuous horce. Stx Incisor teeth of dogs were moved bodily in a labial direction. Reitan caxcluded: When light continuous forces ( $45-55$ grame) were used to move teeth bodily. rock resorption did not cccur. The same forces or even lighter forces, when used to tip teth, would cause root resorption. He further reported that all teeth moved bodly were displeced more coronally than in the apical portion of the roct. This he ascribed to the mechanical resistance created by teeth with long roota, rather than a mechanical deiect of his appliance design. 
In 1961, Reitan reported on the behavior of Malasez Bpithelial Rests during orthodontic treatment. Ho classilhed diterent morphologle types of epithellal reet cell in diferent animale, and compared the cellular morphologic typo to their location in the periodontal apace. In monkeys ho reported the large round type were present. There were fewer epithellal raste in monkeys than in dogs, but the cells appeared more numerous in the apical region and at the bifurcations o. rocts. He concluded that direct bone resorption has no vibible effect on apithelial rests. They atayed cloae to the comentoblasts curing tocth movement and after retentica, returned to their nomal poaition. Hyalinization of pariodontal flbors due to excesalve forcas caused atrophy of the epithelial rests. A secuela to undarmining resorpticn was the disappearance of the epithelial cells of Malagso:. On the cension aide, tooth movemont may reault in acme compretsion of epitholial cells betwoen the atretched collagenous ruber bundles, but the cells are moved caly sllighly away from the roo surface and return to their normal position after retention. Reltan defines hyalinization as being formed by sever comprestion of collagenous hbers causing a cloar, translucent structureless mass which delays 
tooth movement and must we resolved by the process of undermining resorption.

Hwetner and Whitman (1958), in experiments on monkeys using the edgewise appliance, showed thex teeth could be extruded or intruded without damage to the vitality of the pulp. They dascribed the histologic picture and approkimate torce magnitude thelt appliances fenarated. They did not detexmine whether the experimental teeth were tipped along with balne intruded or extruded. They described how the direction of the periodontal fibers changed to follow the line of movement of the teath.

Storey and Smith (1952), in a well deafgned experiment, found an optimal range for maximum rate of movement of mandibular canine teeth. To move these teeth, they ueed hellcal loop springs with calculated force magnitudes and spring rates. They did not atudy the histologic picture because they were applying these forces to the tewth of human beings. Measurements of the amount of movement of the canine tooth and the anchor unit were made weekly by using a Ixed point in the upper law for a reference. They measured the distance betwoen the fixed point and a point on the canine tooth and 
one on the anchor thit. These measurements were made by means of needlo polnted calpars and they were remardad as bolnt accurato to the norest $1 / 100$ th of an inch. They concluded that thate is an optimum range of prossure on the tooth-bone interlace wheh produces the naximum rate of tooth movemont. Fo* pressures below this optimal range, thore is linle movoment of toth and this means that chisctive anchorage can provaly

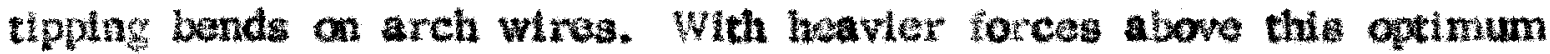
range, tooth movemont appear to ccur by undermining resorthton of Lone. Their calculation of the forces genorated by the applances was documented by placing wach appliance on an instrument and

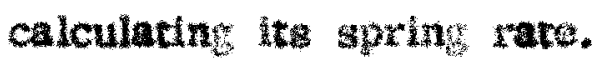

Went, Jaraiak and Orban (1958) conductod tooth Jigrting exporiment on dix Rhosus Macacus nonkeys. They created cuspal interterences in a bucal-lingual diton by deatgning an orthodoutic Lorce system which would produce toch Jywting and thus cause traumatic ocelusion. The histologic sectoms ahowed the jighled teoth had enlarged perlodoutal Igaments manisoting an abunchas of

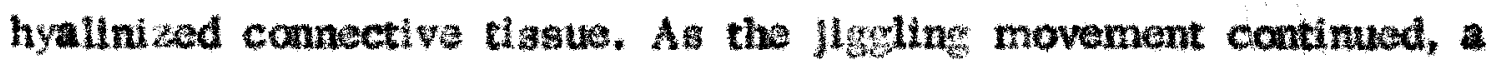


cycle of crushing, undermining resorption, and repair took place in the periodontal structures. A definite pressure or tension side did not etist, but rather the combined effects of both pressure and tension were recorded as the tocth was jigclod uccally and lingually. The combined effects of pressure and then tension were recorded as thrombosis of blood vessels and necrosis of the periodontal Ifgament tollowed by resorption of hone and cementum. As a consequence of the contnued trauma, the resorption of bone and necrotic connective tissue led to an increased widening of the periodontal space until it was more than three times as wide as a non-traumatized toch. Clinically, this widening of the periodontal ligament space resulted in extreme tooth mobility. These findings are of particular interest to the orthodontist since certain aspects of orthodontic treatment are associated with considerable Jiggting. This jugling phenomenon is most prevalent when the inclined plane relationships are changed. And they are even more evident when these movements are compelled to occur with the usage of high friction and high magnitude devices. It then becomes of paramount importance for the ellnical orthodontist to be ahle to analyze force systems and then design appliances which 
will avoid tooth $j \mathrm{fy}$ ling wherever possible or to reduce it to a minimum.

For years orthodontsts have explored the usage of varicus devices to measure the forces orthodontic appliances produce. As already atated in the literature they tried to prowe the phystologic nature of the force produced by their particular type of orthodontic machine. As early as 1920, a small instrument was designed by Borschke to measure orthodontic appllance force magnitudes in the mouth. As explainod by sehwarz, it consisted oi whe bent on itoel with one and longer than the other. A force of twenty zrams would deviate the longer and of the wire $2 \mathrm{~mm}$. from the shorter end. Irigh (1927) devised an instrument for measuring the force and resulting daplacemant of a labial arch wre. He called it the "Irishometer". bulit an the princlple of the calforated spring halance. The balance was oupported rigidy and provided with a gage for indicating lorces, whils the orthodontic applance was moved ovor a Erachated scale that measured displacement.

Bendias (1931) and Richmond (1933) designed push-pull spring: strain gauges to measure roress in the mouth produced by orthodonic 
appliances.

Peyton and Moore (1935) deviaed a aimple apparatus for investigating the properties of orthodontic cantilever and reflex springs. It allowed them to measure lorces applied at more than one point. They used a mounted short range traveling telescope with cross hairs that could be locused on the upper side of the spring being teated. The aprings were heid in place by a pin vise and laded with welght incroments. Storey and Smith used this same type of apparatus when they ploted defiection-load curved for the heliesl springs in their exportment.

Jolms, in 1953, measured the and auxillary opringe by moan of an eloctronic gauge. This gatge congsted of a trangducer, an ampitiler, and an ink writing oscillograph. The inatrument was cenditive to force vartacion of co tenth of aram, and with it they determined force ranges for the edgewise, labio-lingual, and twin-wire appliances.

Vestevich and White (1953) designed a load and dallection apparatus which consisted ot two mounted atages. The smaller atage could be moved by a lad acrew handle attached to the base of the 
larger atage. Bracket mountings and pin viges were placed in various positions on the smaller stage to secure the orthodontic appliance. The lineax displacement of the smaller stage was masaured on an extensometer. Magnitude of the applied force was measured by a force gauge mounted on the large fxed stage. Since this force gauge had a definite compliance, a correction curve was used to determine the true deflection values.

In a recent text (1963), Jaratuk and Fizzell have aystematically presented basic knowledge in the disciplines of analytical mechanics and applied physics as related to biology. This they fused into a new science, "Biophysics of Orthodontic Forces", the principles of which must be applied to an experiment of tocth movement if it is ever to attain the level of a scientific investigation.

In the first chapter, they define a rorce as the action of one body upon ancther. It may be sither a pugh or a pull. From the orthodontiat's point of view, the Important characteriatics of a force are its peak magnitude, polnt of application, line of action, direction. and rate of chanye. Although we may often talk about angle force. forces do not ccur singly. The croation of one borce gives rise to 
at loast one other lores and oiten to a series of lorces. The understanding of the principles Involved in this diacuasion o " coupled with the comprehension of how they apply to blologic principles, were necosary and usecul tools in the saptimental dealgn used to structure this pisce of research. 


\section{METHODS AND MATERIALS}

A. Animal Care and Fooding

Two lemale Macaca Mulatta (Rhesus) monkeys were used in this ressarch and procured trom Shamrock Farms of Middletown, New York,

The animals were housed at Franklin Bouleverd Howpital's Animal Rescarch Conter, Chicago, Illinois. The animals were given labeled tago (MI and M IV) so that they could easily be identhied.

Animal teed conslated of a daily ration o. Purina Monkey Chow, a Lenana, and a vitamin-injected orange. The hard Purina monkey biscuits wero soltened with water to the consistency of a moist mash so that when the orthodoatic appllances were cemented into place the mastication of hard foods would not daiorn them.

B. Animal Handling and Anesthetization:

After a two week colonization period, experimental procedures were begun. Caps, gowns, face masks, and gloves were worn to procect both the animal and the operator from tniections during all procedures in which direct contact with the antmals was made. Each animal was placed into a special "squecze cage" of a predetermined weight prior 
to anesthesia adminigtration. The cage and animal were weighed to otain a rough estimate of the animal's weight. The monkey was then restrained by compresstng the movable wall of the "squeeze cage". A sliding wall of the cage was then opened so that one of the monkay's logs could be freed. The ireed leg was shaved, scrubled with scap and water, and clesnged with alcohol. The skin of the log was then prepared for the intravenous injection of a general anesthetic.

The monkeys were aneathetized by intravenous injection with $50 \mathrm{mz}$. of Nembutal sodium per ave pounds of body weight. Once the animals were under aurgical anestheaia, they were moved to the operating talle and a surure was placed through their tongue. This allowed the operator to pull the base of the tongue away from the oral pharynx whenever the alrway became obstructed. An ophthalmic ointment consistiny, of Butyn Sulfate and Mctaphen, was placed in each eye as a precaution agalnat postoperative aye infections. The weight of each monkey was recorded at this time. Monkey $M I$ weighed 7.5 pounds and Monkey M IV weighed 6.7 pounds. This regime was adhored to in all operative procedures. 
C. Securing Plaster Models and Intraoral X-rays:

Prior to taking impressions and $\mathrm{x}$-rays of the teeth a caretul examination was made of the oral cavity and supporting structures. Acrylic impression trays were formed on the dental arches of a rhesus monkey dry skull. These acryllc impression trays were then painted on their inside suriaces with rubber adhesive. After the achestve had dried, Cos Heavy Rubber Base impression material was mixed according to the manufacturer"s specitications and placed Inside the trays. Then the trays were seated over the dental archos. From these impressione, study and working models of the dental arche were labricated by vitrating properly mixed Vel-Mx Class II stone into them.

Poriapical radiographs taken at this time were used to astablish the stage of dental development $\alpha$ the monkeys and to enable the researcher to oiserve any abnormalities of the rock of the tevth or aupporting structures.

The intraoral examination revealed the presence of twenty-efight permanent teeth in the dental arches. Third molars had not yet arupted. This information, coupled with the intraoral radiographic 
examination, allowed the operator to approximate the monkey's age. Using Herme's Table of Emergence of Permanent Teeth in Rhesus Monkeys, these animals were estimated to be three to four years of a.s.

D. Selecting the Teeth to le Moved Orthodontically:

From the atudy models (Migure 1) of the dentitions of these monkeys, it was observed that owing to the high inclined planes of the posterior teeth and the bigh degree of buccal overjet, banding the mandhular teeth would not be possible. On the other hand the large maxillary buccal vestibule would accommodate a system of helical loops needed to luthll experimental requirements. Therelore, the maxillary let and right first and second premolars and irst permanent molars wore bandod. On the maxillary right ands, brackets would blaced to receive the experimental force systems. Halical loop springs would be used to depress the second premolar tooth while the Arst molur and first premolar teath were used as anchorage units (Figure $6, A$ and $B)$.

5. Designing a Method to Measure Tooth Movement: 


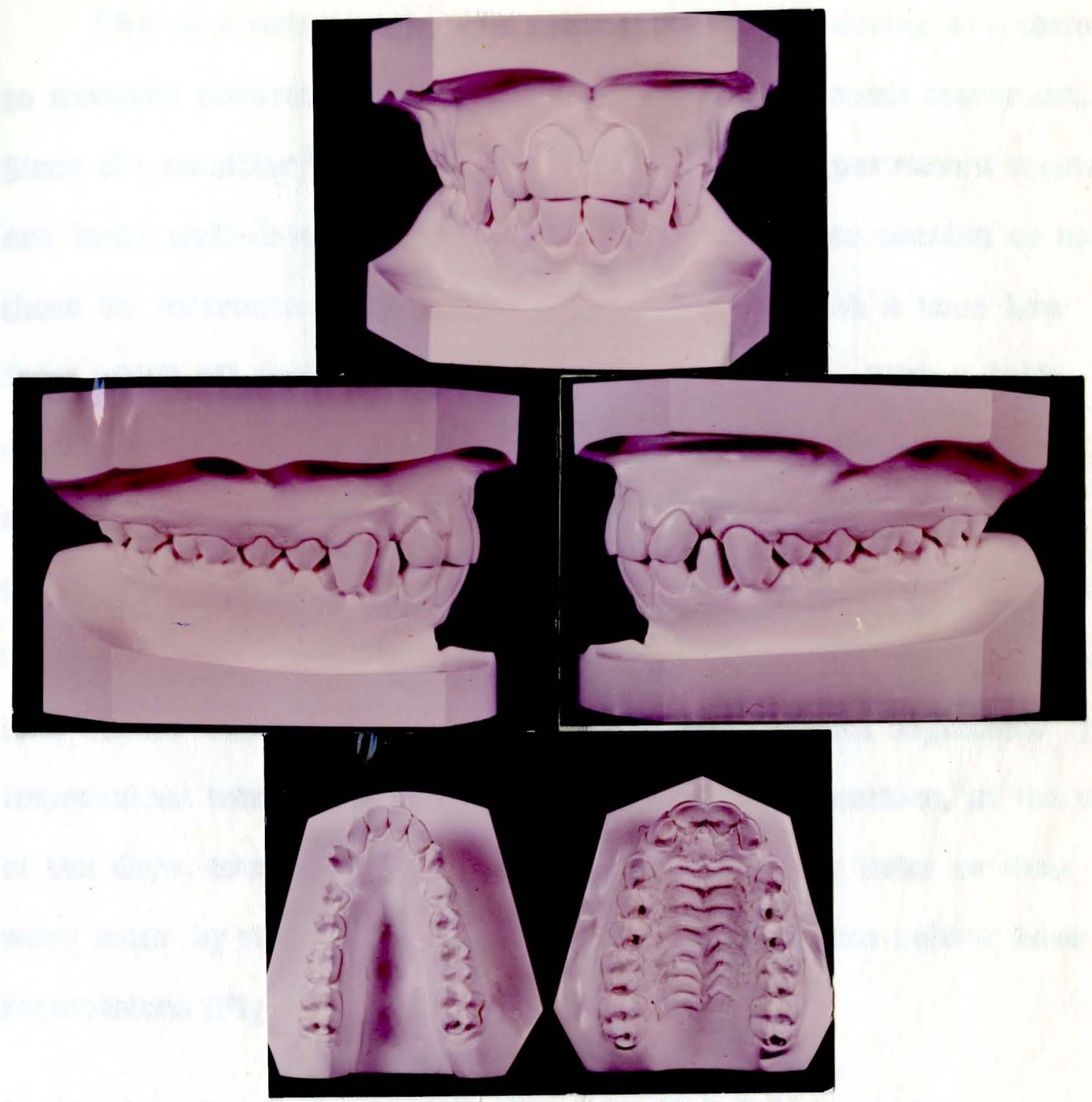

FIGURE L

MONKEY STUDY MODELS 
The noxt objective in this experimem was to deviae a system to moasure accurately the degroe and direction of tooth movenent. since the maxillary permanent canines and second permanent molars are large well-developed teeth in the monkey, it was decided to use those as reterence teeth. These teeth would establish a hase line from which all tocth movement would be measured. With a knife edred diamond disk cross hairs were cut into the buccal enamel surtaces of the maxillary canines and the mesial buccal cusp of the second permanent molars. Small acrylic buccal quadrant trays were fabricated from the study models. These trays were used to take rubber base impressions of the maxillary buccal gegments. These impressions were taken at the time of appliance Insertion, at the end o. ten days; twenty days, and thirty days. Transfer units or dies were made by vibrating Kerr *... Stono Into these rubber base impressions (Figure $2 \mathrm{~A}$ ).

P. Registration Instrument for Transfer Unit Orientation:

An instrument was then designed to accept these transier units and to orient them to estallish a reference plane rom which individual 


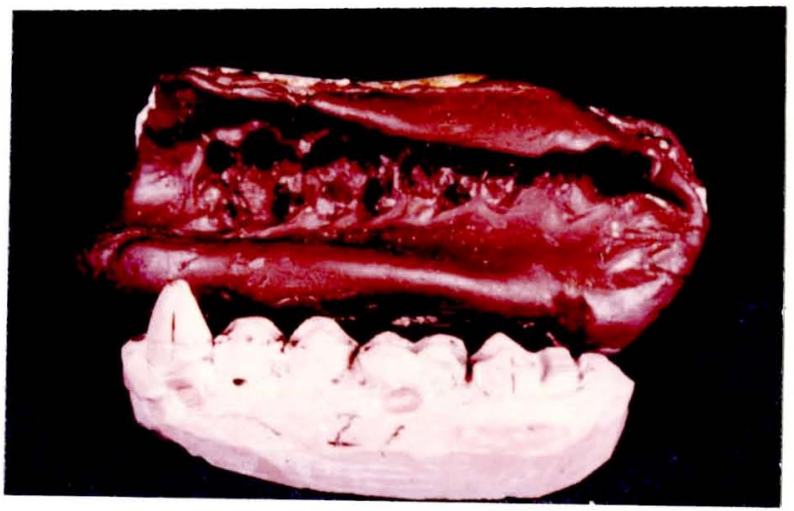

B.

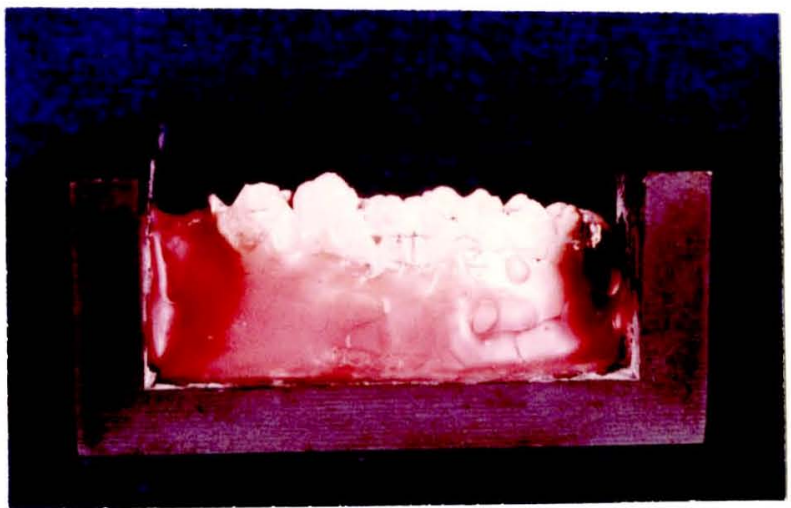

FICURE 2

A. TRANSEER UNIT AND TRANSFER UNIT IMPRBSSION

B. TRANSFER UNIT MOUNTED WN CARRIER 
tooth movements could be measured (Figure 3). The instrument consisted of three Ixed points of reiterence which would accept the transfer units. These reference landmarks were a point which would acceat the center of the cross hatches on the canine tooth, a line whlch would accept the hortzontal slok inscribed on the molar teeth. and a plane which would contact the mesial lingual and mesial buccal cuaps of the maxillary second molar toch. Five carrier devices were milled from steel to hold the transfer units in respective oriented position. The carriers were placed nush against the se and vertical wall o the mounting instrument. The transter unit was placed within the confines of the carrier and oriented to the point, line, and plane. Then hot base plate wax stablikted the tranafer unit to the carrier in Its orlented position (Figure 2 B).

G. Tooth Moasuring Instrument:

An Ames Dial Gauge, extensoneter, or dial indicator graduated in $1 / 1000 \mathrm{~mm}$. per division was fastened sacuraly to an aluminum backplate (Figure ). A thed horlzontal stage was also mounted on this backplate with the measurin: stylua of the dial gauge projecting 


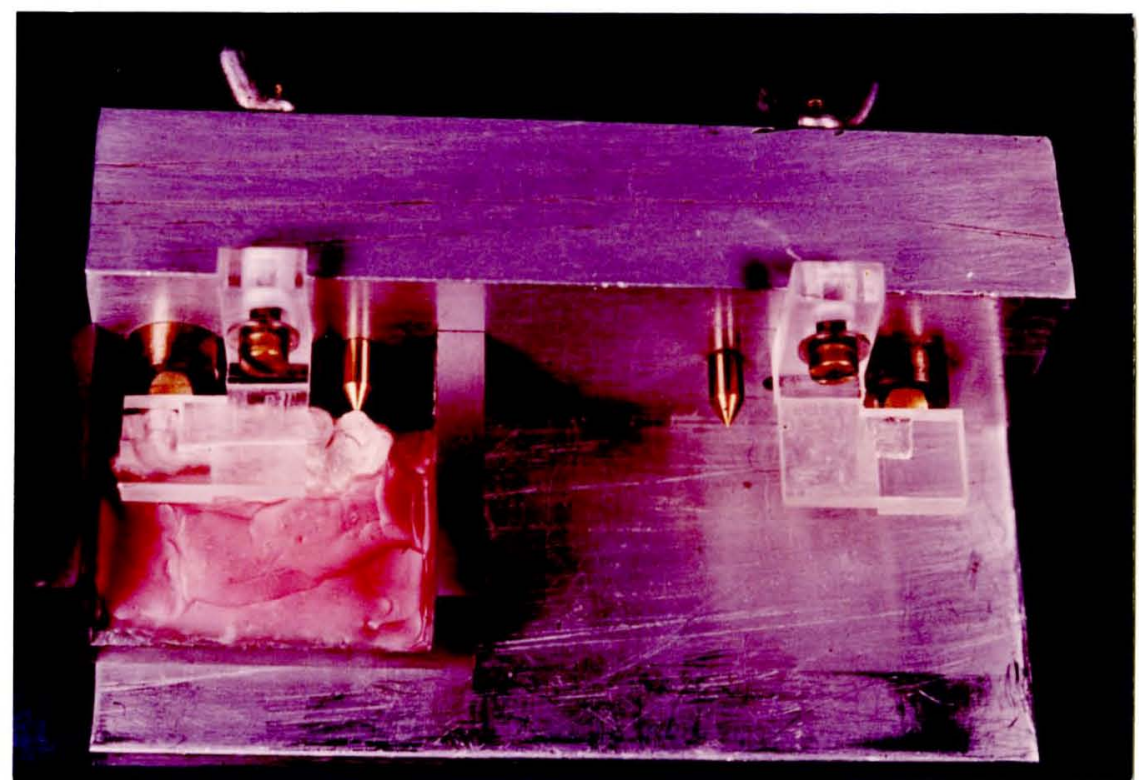

FIGURE 3

REGISTRATION INSTRUMIENT FOR TRANSIER UNTT ORIENTATMON 


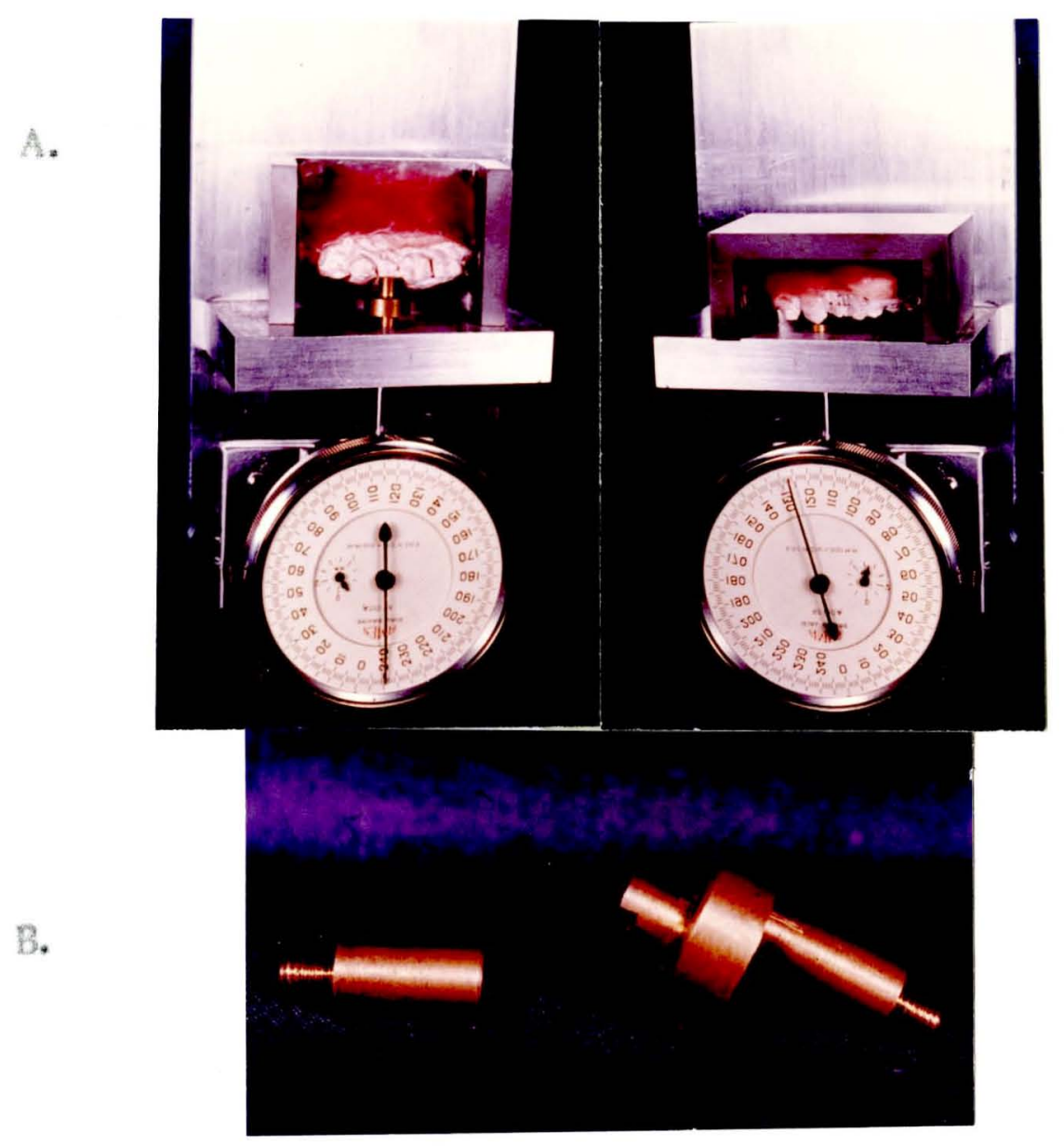

FIOURE 4

A. WSTRUMBNT TO MBASURE OCCLUSAL-GINGVAL AND BUCCAL- - WNGUAL TOOTH MOVEMENTS

8. STVLII OF THE DYAL, GAUGE 
up through the atage. Appropriately shaped measuring stylii could te attached to the spindle of the dial gauge to contact specific perts of a tooth.

The atylus for contacting the tip of the tuccal cusp of a tooth to make occlusal-gingival measurement had just a plain flat end, perpendicular to the long axis of the stylus. An attachment to this stylus was used to make buccal-lingual measuretnents. This attachment was a short cylinder having an eccontric mounting hole on one and and a short protruding boss centrally located on the opposite end. This boss had a small step milled across one alde of its outer face llke a gecant. This attachment could be placed on the previously mentioned stylus, suitably oriented, and locked with a set screw. The transverse step deacribed was made to accept the buccal cueps of teeth during the buccal-lingual measurements.

To make a measurement on one of the transiler units in an occlusal-gingival direction, the carrier containing the mounted transter unit was placed on the horizontal stage with the occlusal auriace acing the proper stylus.

To make measurements in the buccal-lingual direction, the 
transier unit was positioned so that the buccal surace laced the appropriate atylus and the cusps could engage the aforementioned step cut.

1. Testing the Prociston o Measurement

SInce the principles involved here constitute a new physical method of messuring experimental tooth movements it was necersary to devise test to asadss the preciaion o monauramants taken with the instrument.

Five asmple transfer units were orlented on the registration Ingtrument and luted to tive carrier devices. Each unit was given an identification numbor. Four different operators measured the first and second premolar and 1 ret permanent molar on the transfer units bucco-lingually and occluso-gingivally. The units were selected for measurement at random and duplicate mossurements were made by each operator.

The resulta of calculating these 210 measurements are shown in an "Analysis of Variance Table" (Tablo I soe page 31).

The standard arrot of duplicate measurements, derived by 
taking the square root o the duplicates mean squere, was .0107 mm. With the knowledye that this was derived from 120 degrees of freedon we can say the $90 \%$ conlidence limits are plut and minus $.02 \mathrm{~mm}$. Now it was necesanry co determine whether this was a ressonable Ifure that was nelther too by nor too little. We have to conelder that these measuremente were made on a dial indicator the leagt count of which was .001 $\mathrm{mm}$. The 999 confidance limits are then twenty-eight times the least count $o^{\circ}$ the alal indicator. This to not an unreasonalle estor becatse of the fact that the measuremonts were made on casta; apacing was involved and some shifit errors occurred when setting the casts owto the measuring instrument. This error is Whity leas than . Os of mm, and is very mall error to be occurrting in making atch neasurements as those enployed in this

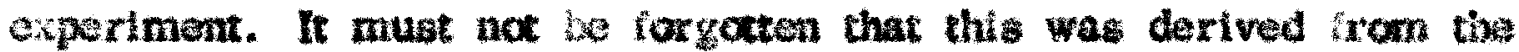
moan aquare due to duplicate mosurements which ahould represent the ineac precigion in the entire experimeat.

To get an ides of the precialon of messurement that is involved in the complete process of handling these casts and applying them to the eest fixture, we obgerve the reaidue mean square that was dorived 
from eighty-seven degrees of freedom. The standard deviation obtained from this mean square estmates the experimental error in the overall process of applying these casts in six different positions and then measuring them.

The two diagrams in Figure 5 represent normal distributions. The limits that are shown on these two diagrams are the $99 \%$ confidence limits for the process of residue atandard error and for the process of taking duplicate readings. The $99 \%$ confidence limits derived from elghty-seven degrees of froedom and the mean square due to residual error are plus and minus $.0936 \mathrm{~mm}$. or about one tenth of a $\mathrm{mm}$. The two superposed distributions indicate that the precision of mensurement is much better for duplicate meagurements than for the complete experimental procedure.

The "Analysis of Vartance Table" lists the separate sources of variation, such as the diference batween units, the difference between the performance of atudents, the differences due to the various teeth that were measured, and the direction In which these coeth were measured. Thene sources of variation, when taken alone or togethor as Interactions, revealed the signiflcantly large aums of squeros or 


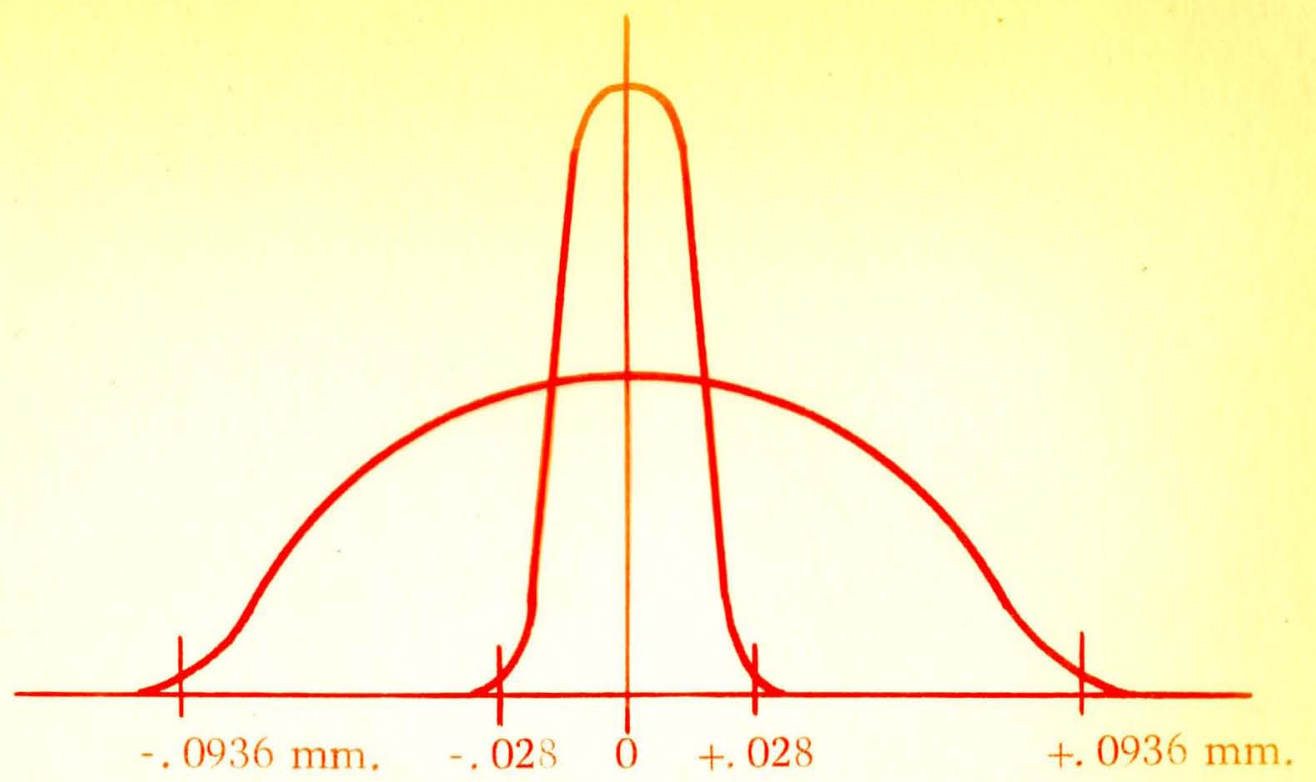

A mean square of .001266 yields .0355809 as the standard error of measurement. $99 \%$ limits are $+/-(2.63 \times .0356)$ equals $.0936 \mathrm{~mm}$. which includes all sources of experimental error.

A mean square of .00011515 yields .01073 as the standard error of duplicate measurements. With 120 degrees of freedom, the $99 \%$ confidence limits are $+/-(2.62 \times .01073)$ equals .02811 mm. 


\section{ANALYSIS OF VARIANCE FOR THE PRECISION \\ MEASUREMENT TESTS}

\begin{tabular}{|c|c|c|c|c|c|}
\hline & D. F. & S.S. & M.S. & V. RATI & F. \\
\hline UNITS & 4 & 2. 741398 & .685349 & 541.4 & $3.56(.01)$ \\
\hline STUDENTS & 3 & .005323 & .001774 & 1.5 & $2.72(.05)$ \\
\hline TEETH & 2 & 5.823006 & 2. 911503 & 224.8 & $4.87(.01)$ \\
\hline DIRECTION & 1 & 54.545926 & 54.545926 & 14.37 & $7.71(.05)$ \\
\hline U. $\times$ T. & 8 & .103953 & .012994 & 10.3 & $2.75(.01)$ \\
\hline U. $x$ D. & 4 & 15.181872 & 3.795468 & 2998. & $3.57(.01)$ \\
\hline T. X D. & 2 & 18.824383 & 9.412191 & 251. & $4.87(.01)$ \\
\hline T. x D. x U. & 8 & .300263 & .03753 & 29.64 & $3.55(.01)$ \\
\hline RESIDUE & 87 & .110142 & .001266 & & \\
\hline DUPLICATES & 120 & .013815 & .00011515 & & \\
\hline TOTAL & 239 & 97.650081 & & & \\
\hline
\end{tabular}


mean squares.

In order to determine significance, comparisons were made Cotween the moan squares resulting rom these vartous sources of variation and the man scaure dwe to reaidue. There are scme instances wherain the mean square due to one ot the three lactor or two actor interactions might have to be used as the raference a ainst which to malco compartion. This is determined by the components of variance that are contained in the respective mean squares.

Looking at the "Analysis of Variance Table", it becomes apparent that the three-factor interaction wae algnilicantly large even when judged at the . O1 level o probability. The two factor interactions wert all signilicantly large. The mean square due to direction was gignifcant when judged at the .05 lavel of probability. The muan square dus to reeth was gignificanty large. The mean gquare due to students, however, was not signiticanty large, even ludged at the .05 level of probablicy. The maan square duc to units was significanty lare as axpected.

In conclusion, it can be said that some sighicance was attributed 
to all of the sources of variation and interactions except the students that participated in the making ot these measurements.

1. Determination of the Force Magnitudes

The originally stated purpose of this work was to design and study the effects of a reciprocal vertical force system on the posterior teeth of monkeys. The two premolars and the first permanent molar were chosen to recelve this force aystem while the canine and gecond molar were selected as orientation teeth. One force in this aystem was directed to intrude the second premolar and two reciprocal forces were directed to extrude the two adjacent teeth. The force applied to the second premolar was greater than the force applied to either of the adjacent teeth because they shared the load.

Root pressure is lorce applied per unit of effective root area; therefore an effective orthodontic force should vary with the estimated rook area. Usiag an estimated maximum intrualve horce for a human premolar and estimated effective root areas for the human tock and the monkey tooth, it was possible to set up a tormula to compute the maximum intrusive force for the monkey premolar.

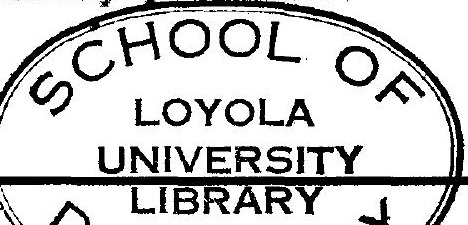




$$
c=a \frac{d}{b}
$$

$a=$ maximum human premolar intrusive lorce $=180 \mathrm{gms}$.

b average roo length of human premolar $=14.5 \mathrm{~mm}$.

c as maximum monkey premolar intrusive torce

d average rock length of monkey pramolar $=9.6 \mathrm{~mm}$.

$$
c=180 \times \frac{9.5}{1 \frac{1}{3.5}}=121 \mathrm{gms} \text {. }
$$

1. Designing and Analyzing the Force System:

The appliance used in this force syatem consisted of two hortizontal holical loop spring with one and one hall turns in each hilix (Figure 6). The loops wore fashioned so that when they were activated. the diameters of the hellcal loops would become smaller indicating they were being stresaed in compression. The loops wers placed into the vestibule, one extending anteriorly, the cther posteriorly. The horizontal lege $\alpha$ the loops converged on the maxillary socond premolar. At this point of convergence, vertical offsets were made occlusally to engage the vertical end slots of their respective bracketa (Fifure 6 B). By securely IGating the vertical extensions the appliance 
A.

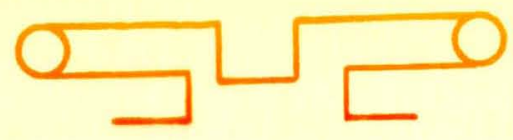

B.

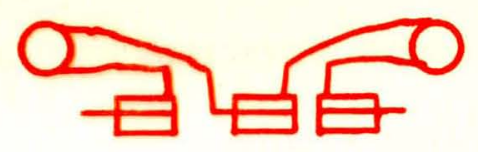

c.

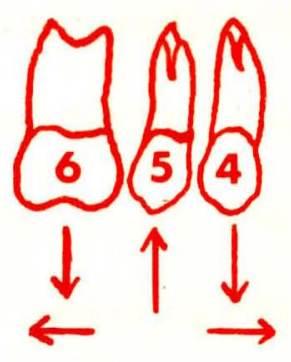

$\oplus \odot \oplus$

D.

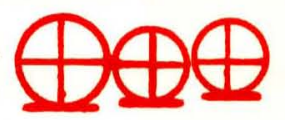

$\odot \oplus \odot$

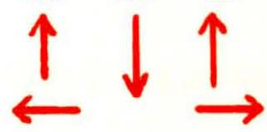

A. APPLIANCE UNSTRESSED

SYMBOLS

B. APPLIANCE STRESSED

C. BUCCAL ASPECT

D. OCCLUSAL ASPECT

$\uparrow$ VECTOR OF FORCE

( EMERGENT VECTOR

$\bigoplus$ IMMERGENT VECTOR

FICURE 6 
was stabillzed against uccal-lingual displaciment. Since the main slots of the brackets were hor zontal, it was necessary to have horizontal extensions, so that the appliance could be afticed to the brackets of the bands.

For each appliance, the characteristics o force versus distance were meagured on a load-delection testiny machine (Figure A seo page +1$)$ and load versus dellection curves were ploted ror each appliance. Since the Hunter force gauge of the testing machine had a compliance or "follow-alony", correction terms were necessary to achieve accurate moasure of displacement. The measurements ot displacements were corrected belore any calculations or ploting were attempted.

Although the characteristics of an appliance may the ploted on a load-dellection graph, that alone does nox explain the orce systems that were applied to the teeth when the appliance was activated. In order to make thege lorce systema more explicit, it was necessary to use roe lody dagrams (Flgure $7 \mathrm{~A}$ and Plgure $7 \mathrm{~B}$ ). The maxllary first permanent molar and that part of the appliance that was attached to it are represented in the buccal 


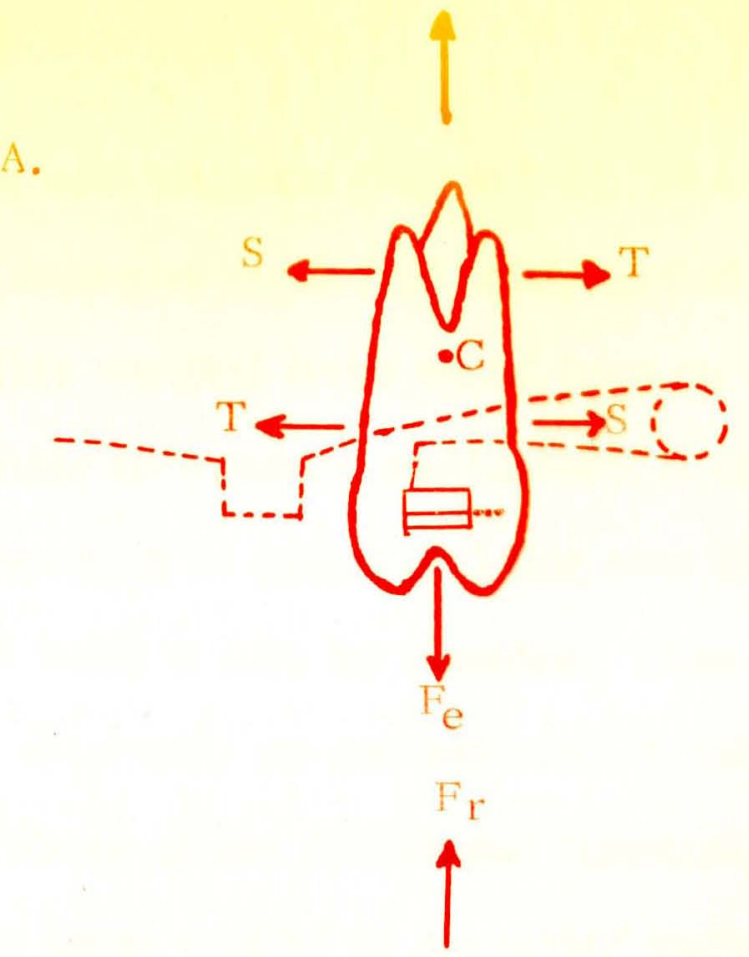

B.

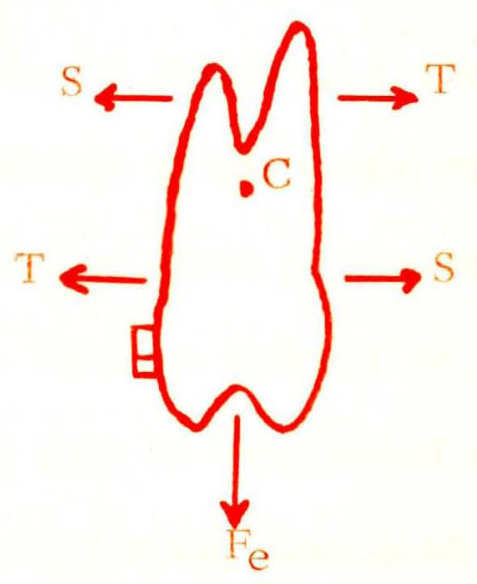

BUCCAL ASPECT
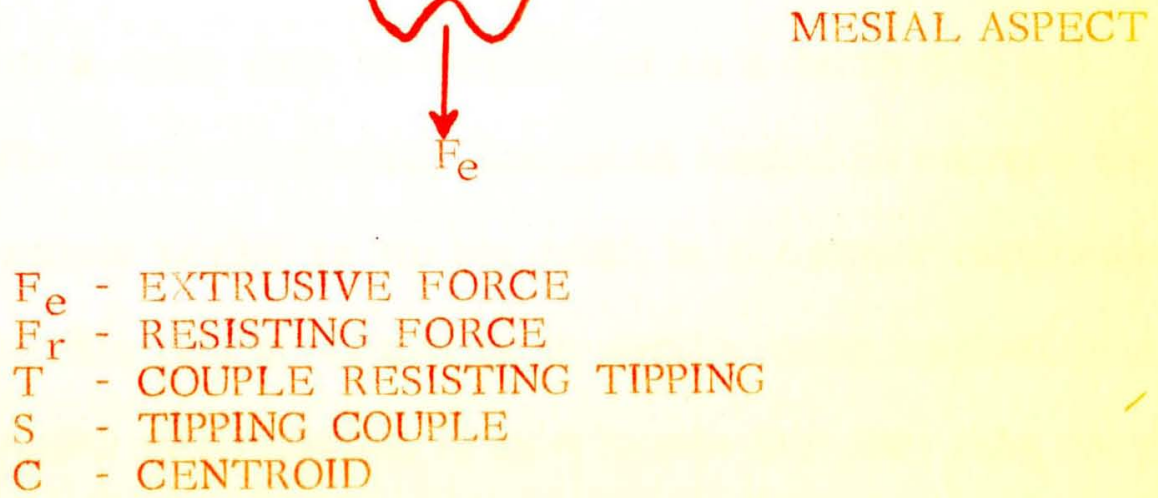

FIGURE 7

FREE BODY DIAGRAMS 
new of the free body diagram (Figure $7 \mathrm{~A}$ ). In effect the molar will have one large axtrusive force (Fe) being applied to it along its central axis. This vertical fores would have an approximate value of 61 grams. In order to maintain equillbrium, it will be necessary to draw a force vector of 61 grams (Fr) that acts along the central axis of the tock and holds it into its alveolus. Thus when we applied an extrusive force externally we can envilion an intrublve force being created by the nbers of the periodoatal ligament. The fact that the initial activating force applied to the molar tooth is not applied alon the long axis of the tooth, but rather at a distance of approximately $6 \mathrm{~mm}$. (at the buccal surface of the tocth) anterior to this contral axis, means that a moment of force is generated that may be calculated to be $366 \mathrm{gm}$. mm. A moment of a torce when applied to the bracket of a tooth may be considered as a lorce (Fe) and a couple (S). The loree already deacribed tendod to extrude the tooth, and the couple tended to tip the tooth in a counter clockwise direction. Since this tipping couple is in reality being applied to a tocth in its alveolar envircament, it is a known fact that this couple will tip the molar tooth about its centrold (C). The fact that the 
toch does not immodiately tip in a dital direction means that the periodontal Ifgament is doveloping a rosisting couple. This couple (T-T) is lormed by the Hiters on the distal apical on-thrd or one.

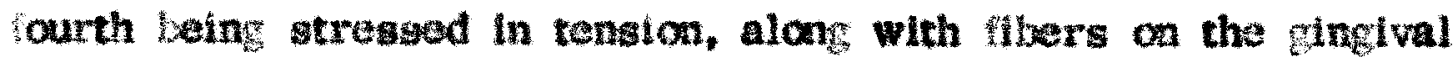
one-third or one-fouth on the mesial side. The combination of these Hers heing stressed in tension will penerate a couple which will tend to gtabilizte the tooth for a while untl the toch begins to move. It would bo posable to describs a simllar lroe body diaman or the maxllary 1 rst premolar tooth as the one discussed for the Irat molar. The fact that the force applied to the brecket of the maxillary second premolar is noarly balanced hecaupe of the two aimilar horlycatal loops meang that there would be lttle or no thyng of the tooth in ather a mosial or distal drection.

Viowing the free fody diagram from megal aspect, (Figure 7 b). one can observe that the axtrualve forces applied to the frot premolar and molar toch are no along tho long axes of these texth but rather bomo distance approstmataly four mr. lataral to thet central atos. This generates monent of horce on sach which tends to tip these tech in a lingual direction. The vertical estenaion of the horizontal 
helical loops ligated into the vertical end slots of the brackets produced a resisting counter couple to any uccal lingual tippin. The second premolar with an intrusive lorce being applied to it experlences a tipping moment in a buccal direction which will be resisted $3 y$ the vertical leg of the applance selng ligated into the vertical end slot. If the vertical section of the horizontal hellcal loops ligated into the vertical and slots of the brackets does not produce a large enoun realsting couple, then the thers of the periodontal ligament with the tensions placed upon them will set up a rosisting couple to the tuccal-lingual tipping moment.

K. Appliance pabrication and Testing:

With the hortrontal helical loop applance designed and its orce 3 yatems analyzed, the remaining task o labricating the appliance was relatively simple. In order to secure the appliance to the teeth. bands and hrackets had to be adapted.

The bage of the nonkey working model was keyed and a separating medium applied (Figure B). A second lase o Class II atone was poured and the working model placod on it. The model 


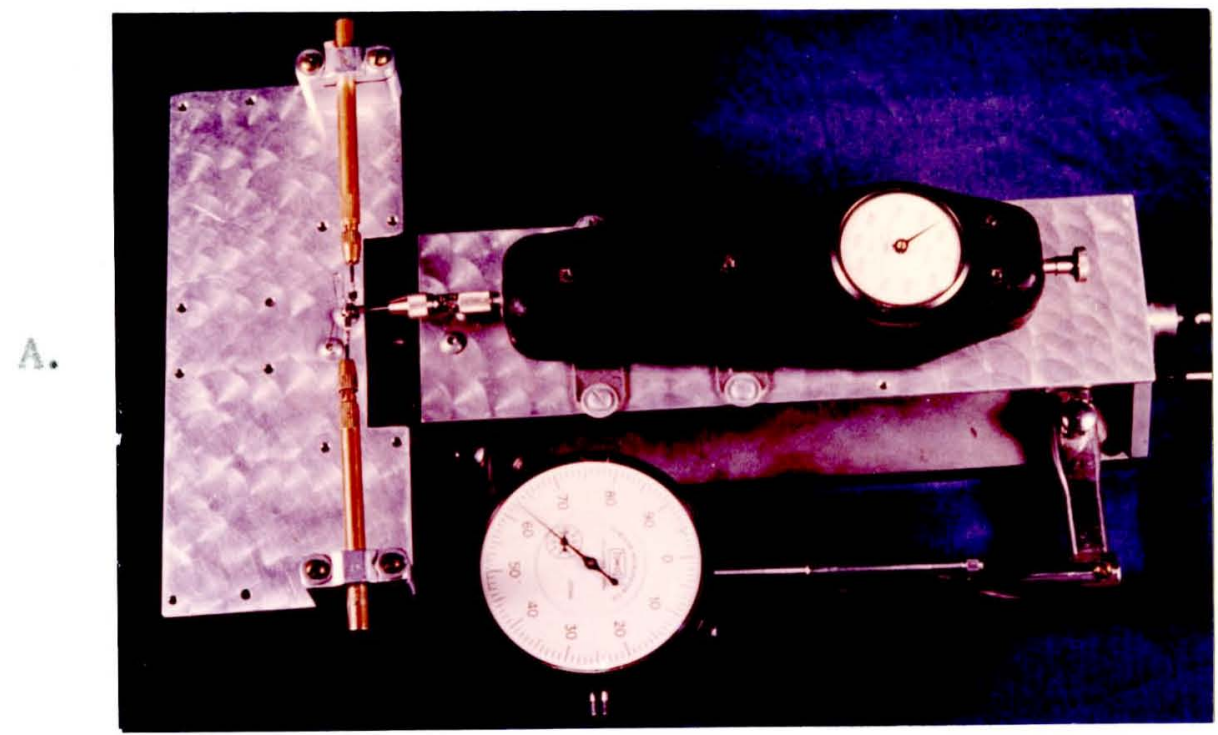

B.

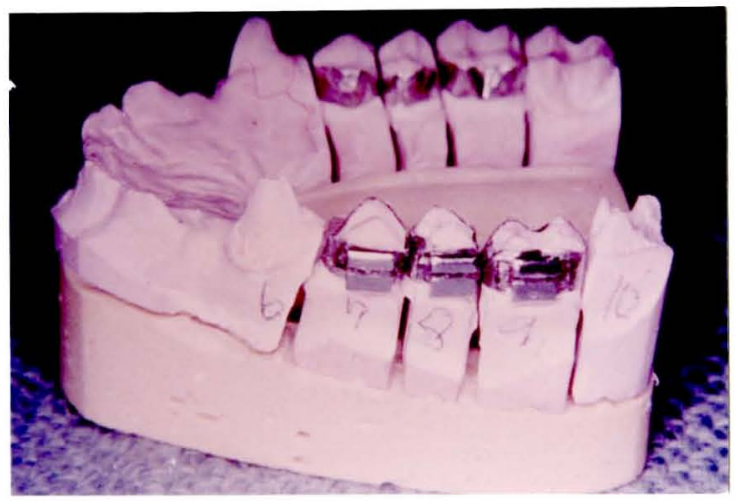

PIOURE 8

A. INSTRUMENT TO CALCULATE LOAD DERLECTION CHARACTERISTICS

B. KEYED MONKEY WORKING MODEL 
was trimmed and each posterior tooth to banded on either side was separated from its adjacent tooth with a .007 inch thick diamond lightning strip. This allowed space for the thickness of hand material to pass through interprosimally. Each took was now sawed from the main model so that it would he separated from the main model. The die tooch could be placed lack at any time into ita original position on the model becauge of ita orientation to the keyed o* serrated habe. Bands were romed on the dies of the maxillary Hirst and second premolar and the Mrst permanont molar on both sides of the maxillary model. Three Jarahak lower inclaor brackets with mestal and distal vertical end slots were ligated to a small piece of .016 by .016 inch aquare wire. The brackets were temporarily attached with sticky was to the right maxillary banded teeth. A stalght aquare wire was forced through these backets to orient them correctly to each othor. The wire was removed and each bracket was spot welded to its respective hand.

The diss, with adapted tracketed hands in place, were then luted into position on the ase of the working model. The lorce 3.tem was then abricated an this banded workns model (7igure 9). 


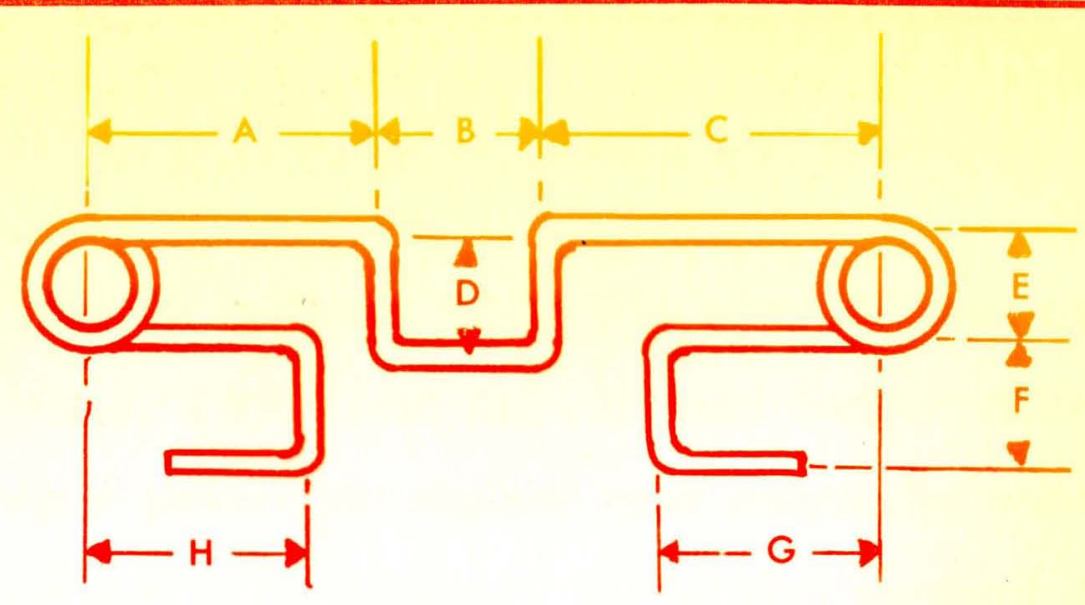

KEY MI APPLIANCE M IV APPLIANCE

\begin{tabular}{l|r|r}
\hline \hline A. & 12.2 & 11.2 \\
B. & 4.0 & 3.7 \\
C. & 11.5 & 12.2 \\
D. & 3.8 & 2.4 \\
B. & 3.0 & 2.6 \\
F. & 3.75 & 2.3 \\
C. & 6.8 & 8.4 \\
H. & 7.6 & 8.2 \\
\hline
\end{tabular}

FICURE 9

DIMENSIONS OF APPLIANCES IN MILLMETERS 
After testing the appliance design with many diterent type and diameter wires, it was lound that .01 inch ductile yellow lylloy wire would produce the desired orce nagnitudea when hent into the conghuration o the horizontal helical loop appliance desizn. All appliances were heat treated in a Huppert electrical oven at 900 dogrees pahrenheit or ten minutes as recommended by tho manuacturer.

Bach appliance was then placed in a device to measure the load-delection characteristics which are graphically Illustrated in Figure 10.

L. Cementation and Activation of the Applance:

The animals were anesthetised as previouly described and the contact of the toeth to receive the bands were removed by passing a .007s inch thick diamond lightuing gtrip between the toeth. The bands were ittud and comented to the teeth with Black's copper cenuent.

After removal o excosa coment, impress ons were taken o. the maxillary buccal quadrant with subbex Lage material. The 


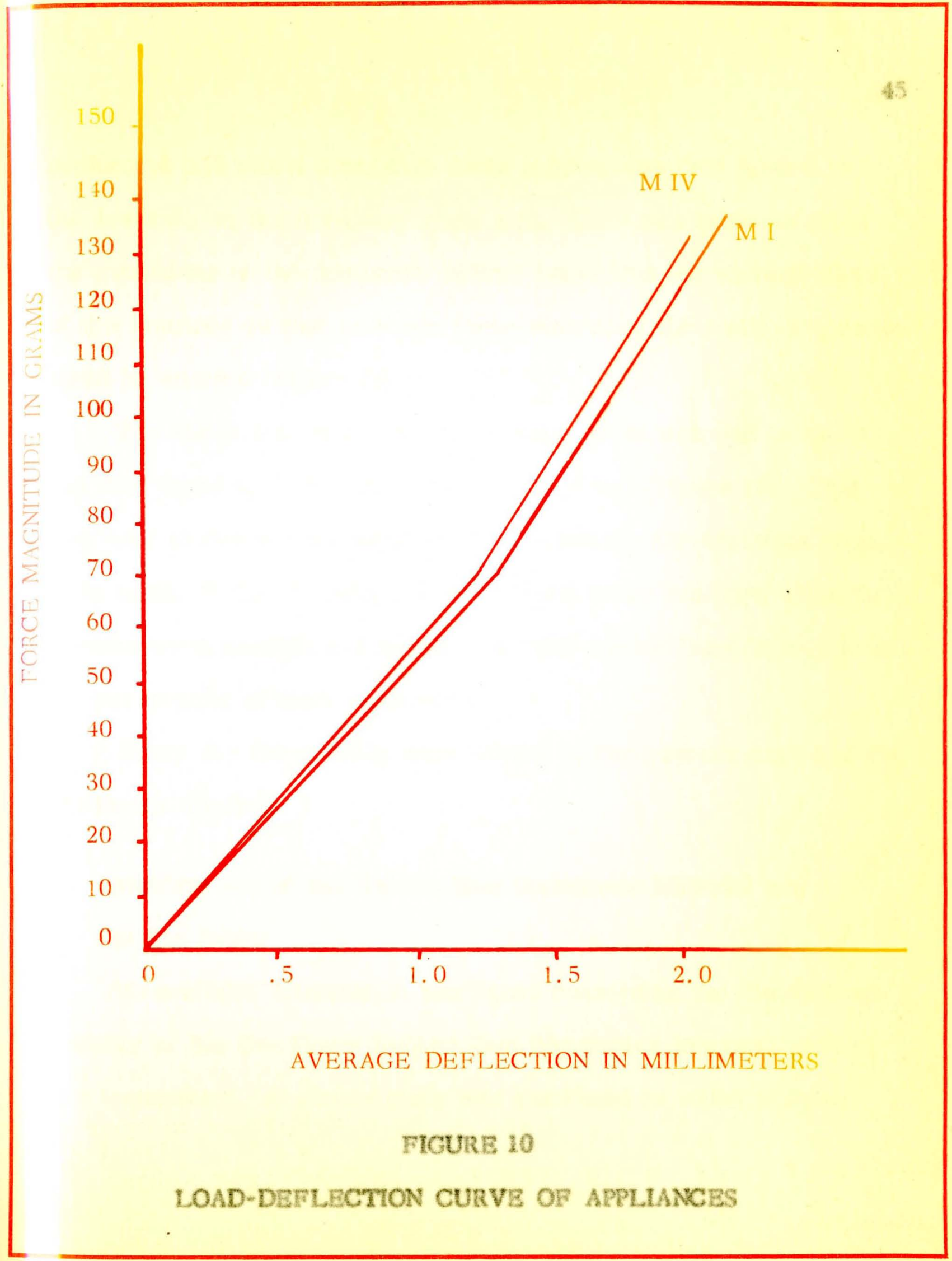


preformed and tosted arch wire hoce $3 y$ stem was then ligated to the trackets on the maxillary right side. Care was taken to place the extensions of the horizontal helical loops into the vertical slots o the brackets so that accurate torce control of the tath in quegtion could attained (Flgure 11).

The hands and wrists of the monkeye were wrapped in gause and then taped to form small mitton-like gloves (Figure 12). This was done to restrain the animals from removing the appliance from their towh. These dressings were changed very ten days when the animals were anestheticed to take quadrant rubber base imprassions or assessmem of tooch movements.

Every day the animals were placed in the squeeze cage and the appliances chocked.

M. Specifications of the Rubser Bage Impression Material and the Die Stone:

No available incomation was found conconin the dimenslonal stablity of the Coe Heavy Ruber Bage Impression material used in this experiment. A ample study was conducted in which a doxen 


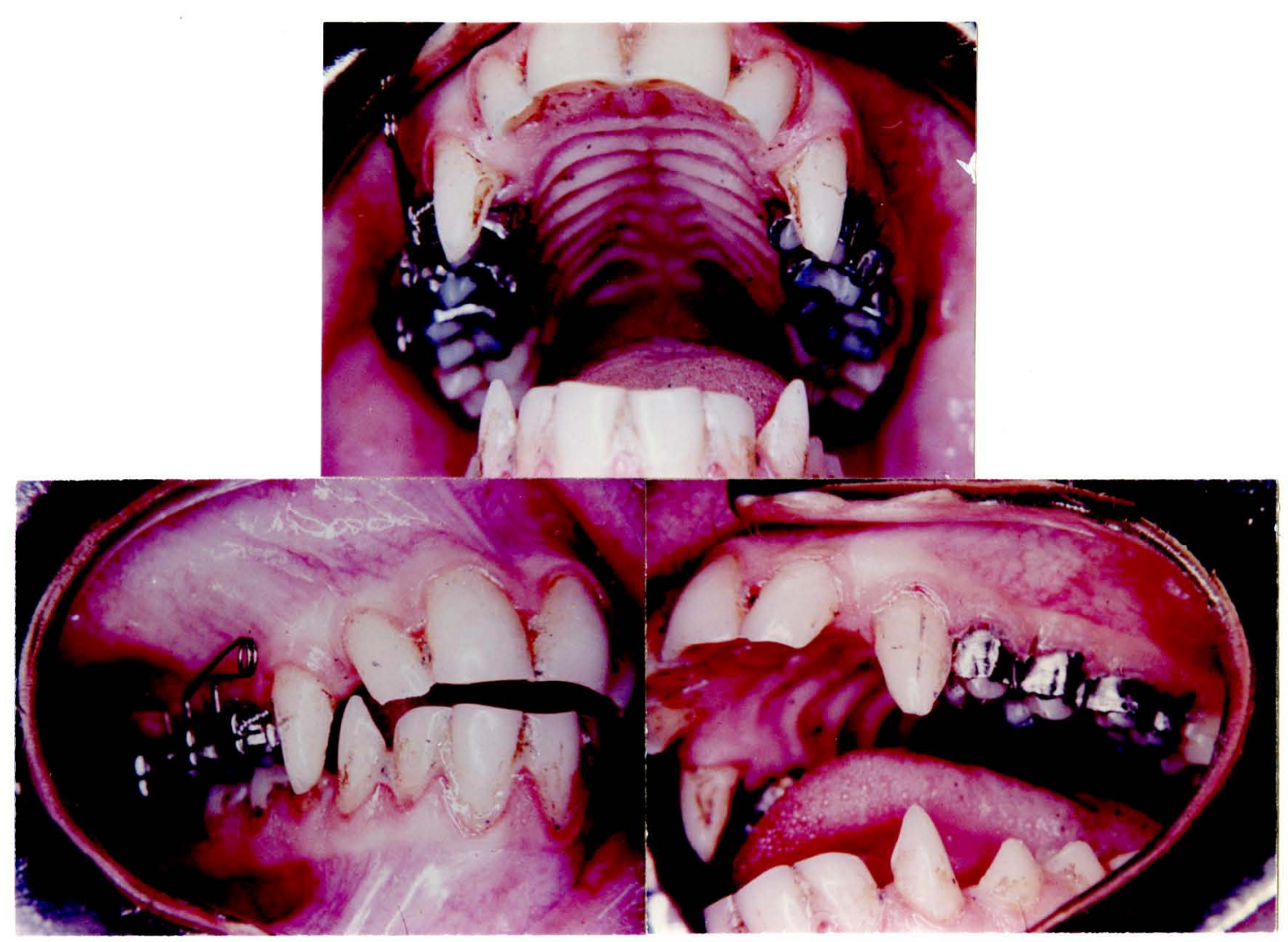

FIGURE $1 \mathrm{H}$

THE MAXI LARY RIGHT STDE AND TIS ACTTVATBD HELICAL LOOP APPLIANCE

TH MANTLLARY LENT REFBRENCE STDE 


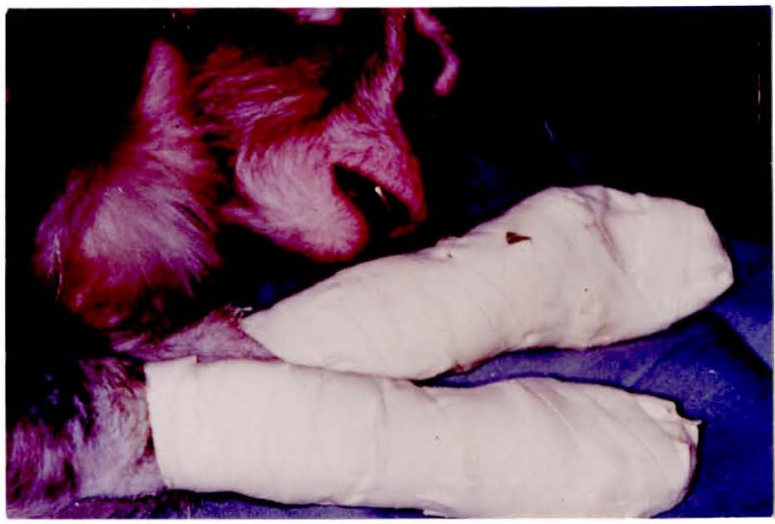

FIGURE 12

THE MITTEN-LIKE RESTRAINING GLOVES 
measuremems were taken. Three mixes of rubber hage impression material were coniluned on the slab by a rectanyular ploce of metal. The samples were then covared with shest of polyethylene and placed in a $38^{\circ} \mathrm{C}$, water bath for goven minutes. The impreaston matertal samples wera then placed on talcumbed glass slabs. Measurements of the distances between the bosaed crosshatchea were taken at the materials seting time, one hour, three hours, and twenty-four hours after getting. An analysis of variance revealed a coofficlem of trariation $\approx 1 / 4$ of $1 \%$.

The putushed recommended water-powder ratio of $25 \mathrm{cc}$, of water to 100 grams of Vel-Mix stone was adhered to when using the material. The crushing strength of dry samples of Vel-Mix stone is over 12,000 pounds per square inch. The setting expansion one hour after bat 20 of $1 \%$.

N. Sacriflcing the Animals and Preparine Tssues by Perfusion Both animals ware sacritlced on the thirticth experimental day. They wore anesthetized and a hap of skin reflected, axposing the let lourth and hth riba and the sternum. The fourth and fith 
niss were removed and the pericardium exposed. The inierior vena cava and the descending, aorta were blunty dissected and clamped. A puncture wound was made into the auperior vena cava and the luid was agpirated. A perfusion cannula was then ingerted through the wall of the left ventricle and fed up the ascending aorta.

Isotonic sodium cirrate at thirty-geven dogres Centgrade was pertused into the aecending aorta. When the clear citrate solution was geen howing out of the suparior vena cava, a ten per cent ufiered neutral formalin solution was introducad into the ascending acrta. When the oral tissue became rigid and the formalin solution was lowing out o the superior vena cava, the perfusion was considerod completed.

o. Histologic Preparation:

The exporimentally noved and contol tech and their suppotins etructures were removed rom the jaws in block sections and immediately iffed in a solution of ten per cent athered neutral ormalin. After ten days of Isation, the appliances were carefully cut fom the toeth to prevent any tissue changes rom the procedure. 
Aiter fixation, the blocka were washed in running water for twelve hours helore decalcification. The risste hlocks were decaldfied in a solution of $10 \%$ formic acid. The formic acid solution was changed Frequently and the tissues were tested with s-ray to ascertain the degree of decalcification. Decalcilication took orty-eight days. The tissues were then washed in water prior to dehydration.

The tssues were dohydrated and double imbedded in celloidin and paraffin and microtome sectioned in the histologic latoratory of Loyola University School of Dentistry.

The blocks were sectioned serially at a thickness o ten microns. The sections were cut mesio-distally in the same plane as the central axis of the teeth on Monkey MI. Cross sections, or sections cut transvergely to the long axia of the teath were made on the tiasue of Monkey M IV. Every fourth section was stained with hematoxylin and cosin. 
CHAPTER IV

FINDINGS

A. Presentation o: Data:

When the mosurements were ortained as described in Chapter III thay were entered in data shets prepared tor this kind o data. Takle II shows ane of these sheats listing the tooth position measuroments obtained rom the transfer units of the naxillary right tecth on Monkey 1. Talle III contains the tooth position measurements made on the transier units of the right maxillary teeth o: Monkey IV. Table II contains measurements made in an occlusal-gingival direction while Table ill containg measurements rade in the buccal-lingual direction.

From the original data it was poswile to calculate the position o each tooth at each examination by averagyng the indepenclent measurements mads by two operators. These average tooth positions were ploted in Figure is for the occlusal-gingival direction and in Figure 14 for the Accal-1ingual direction. Comecting the sequence o pointa for a given tooth in a given monkey vives a graph showing the trend of the tooth movement. There are alt graph lines in ach 


\section{MEASUREMENTS OF OCCLUSAL-GINGIVAL TOOTH POSITIONS OF THE MAXILLARY RIGHT BUCCAL UNITS}

- Transfer Unit No.

1

1

12

2

3

3

4

4

Monkey I
Operator

A

B

A

B

A

B

A

B
4

1.311

1.304

1.582

1.556

1.560

1.555

1.586

1.572
Tooth

5

1.096

.543

1.091

.544

.935

.583

.933

.585

.729

.512

.720

.515

.535

.489

.521

.484

TABLE II 
MEASUREMENTS OF BUCCAL-LINGUAL TOOTH POSITIONS OF THE MAXILLARY RIGHT BUCCAL UNIT

Transfer Unit No.

1

1

2

2

3

3

4

4

Monkey IV
Operator

A

.566

.551

.772

.775

.725

.729

.649

.643

B

A

B
Tooth

5

.540

1.706

.529

1. 711

1. 250

1.773

1. 248

1.777

1. 385

1. 805

1. 384

1. 801

1. 230

1. 529

1. 282

1.531

TABLE III 
MOVEMENTS OF THE TEETH IN AN

OCCLUSAL-GINGIVAL DIRECTION

ON THE EXPERIMENTAL SIDE

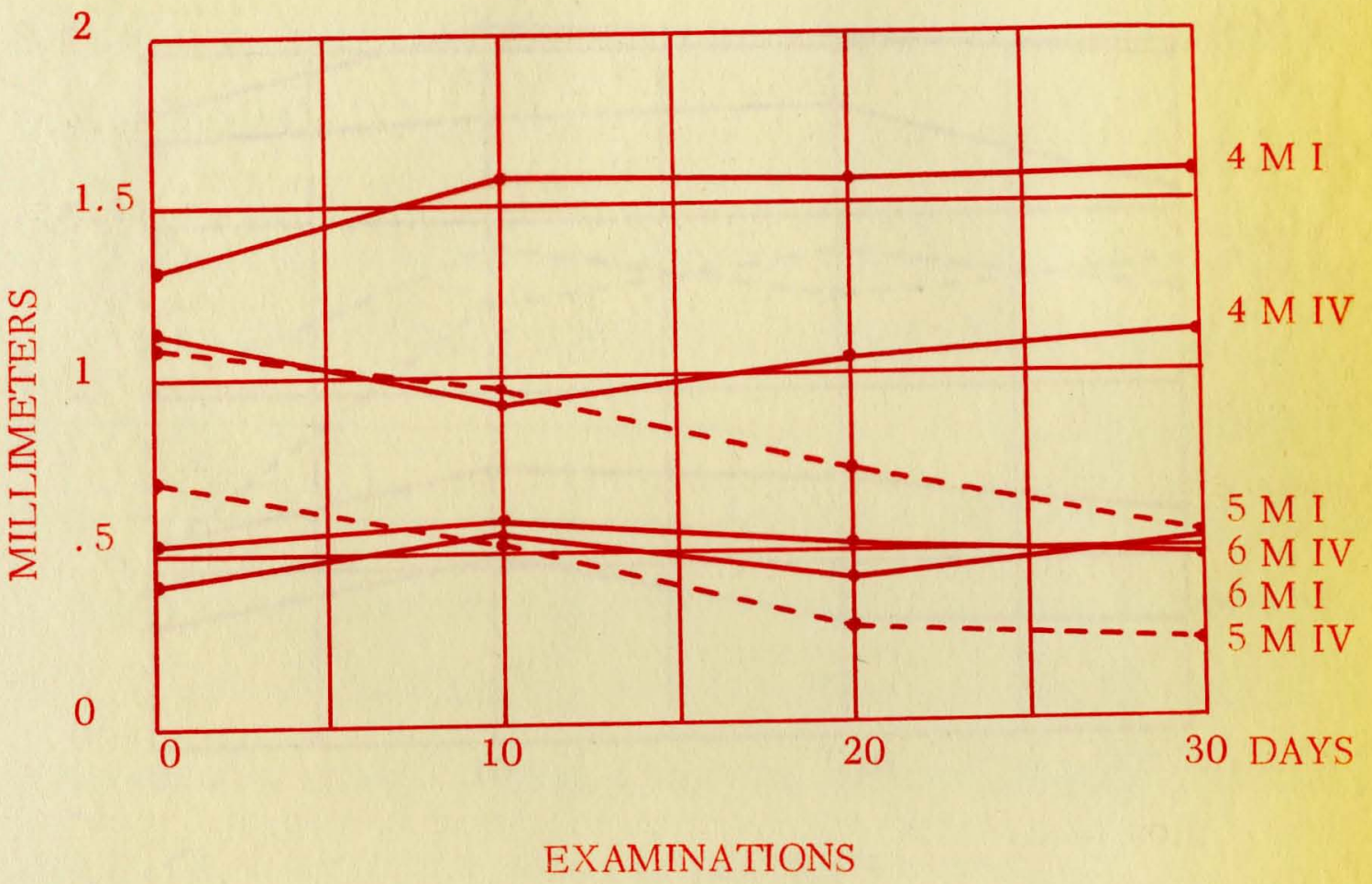

INCREASE IN DIMENSION (OCCLUSAL-GINGIVAL) MEANS EXTRUSION

$$
\begin{aligned}
& \mathrm{M}=\text { MONKEY } \\
& 4=\text { MAXILLARY RIGHT FIRST PREMOLAR } \\
& 5=\text { MAXILLARY RIGHT SECOND PREMOLAR } \\
& 6=\text { MAXILLARY RIGHT FIRST PERMANENT MOLAR }
\end{aligned}
$$


MOVEMENTS OF THE TEETH IN A

BUCCAL-LINGUAL DIRECTION

ON THE EXPERIMENTAL SIDE

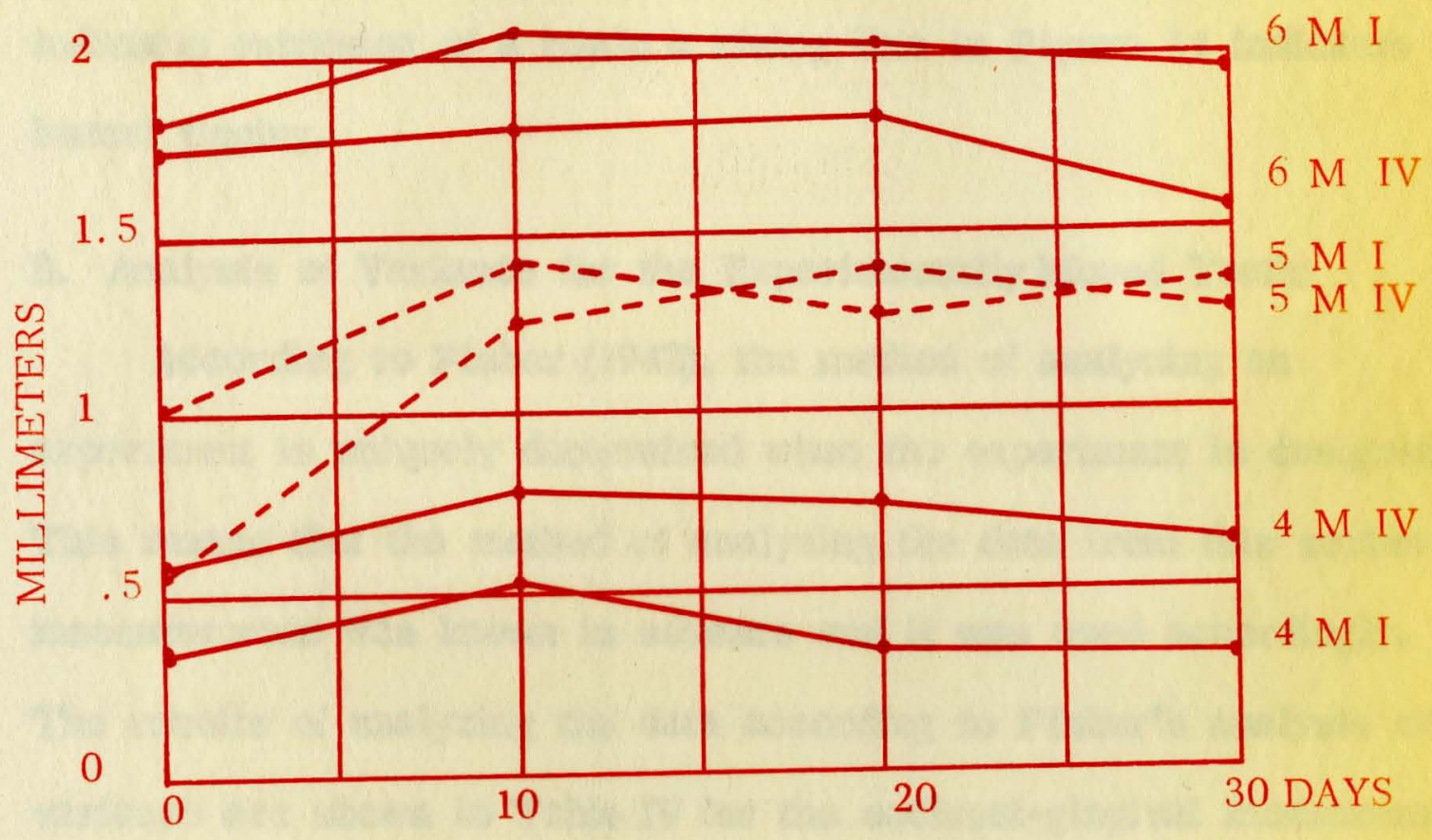

EXAMINATIONS

INCREASE IN DIMENSION (BUCCAL-LINGUAL) MEANS BUCCAL TIPPING

$\mathrm{M}=$ MONKEY

$4=$ MAXILLARY RIGHT FIRST PREMOLAR

$5=$ MAXILLARY RIGHT SECOND PREMOLAR

$6=$ MAXILLARY RIGHT FIRST PERMANENT MOLAR 
one of the Figures mentioud. These are identilied by the legend at the fotom of the respectwa pages. A rising line in Figure 13 Indicates extrusion of a tooth; a rising line in Firure 1 indicates buccal tipping.

B. Analyals of Variance for the Experimentally Moved Teeth: According to Fishor (1942), the method of analyoing an experiment is uniquely determined when the experiment is deaigned. This moans that the method of analyzing the data rom this measuroments was known in advance and it was used accordingly. The results of analyzing the data according to Fibher"s analysis o variance are shown in Table IV for the occlusal-gingival measurements and in Table $\mathrm{V}$ tor the uccal-lingual measurements. According to the results o the ccclusal-gingival analysis, there was enough difference batween the dimenstons of the two animals to Le statiatically bignificant. Because some of the teeth moved one direction and some moved the opposite direction, there was not a siznilicant diference revaled in a study of the ample grose ficts on the teath. It was nocessary to consider tho interactions between 
ANALYSIS OF VARIANCE TABLE

RIGHT SIDE - OCCLUSAL-GINGIVAL DIMENSION
D. F.
S. S.
M. S.
V Ratio

Animals

1

1. 0199587

1.01996

55.59

$13.74(.01)$

Teeth

$2 \quad 5.4505206$

2. 7252603

14. 47

N.S.

Exams

3

A $\times \mathrm{T}$

2

.1451802

.0483934

3. 628

N. S.

A $\times E$

3

.3766850

.1883425

11.29

$8.02(.01)$

$\mathrm{T} \times \mathrm{E}$

6

.0400126

.0133375

$<1$

N. S.

A $x$ T $x$ E 6

.5886179

.0981029

5.88

$5.80(.01)$

Duplicates

24

.1100825

.0183470

Total

47

.0009135

.0000380 
the tosth and oxher actors auch as animals and eraminations to learn about the significant motions of the tech. The ame explanation applies to the resulta of the measurements made during succesalve examinations. These "main etrects" do not reveal any big changes and herein lies the advantage of the analysis that displays the interaction between actors.

The analysis indicates that the Animal $*$ Tooth interaction was large enough to be significant. The muaning of this interaction is displayed in the graph of Figure 15, A where it can se seen that

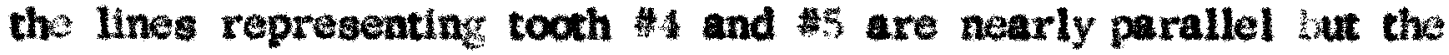
Ine representing tooth 6 is not at all like the oher two. This lack - paralleliam displays the exact type of interaction between Animals and Teeth.

The analysis also ahows that the Tooth $\mathrm{zxamination}$ interaction was large enough to warrant further study. A graph showing this interaction is shown in Figure 15, B. Again, the lack of parallelimm of the graph line serments indicates the nature of the interaction hetween these two actors.

The Animals $\times$ Examination interaction and the Animal $\times$ Tooth 
A. RIGHT SIDE - OCCLUSAL-GINGIVAL DIMENSION. INTERACTION BETWEEN ANIMALS AND TEETH.

TEETH

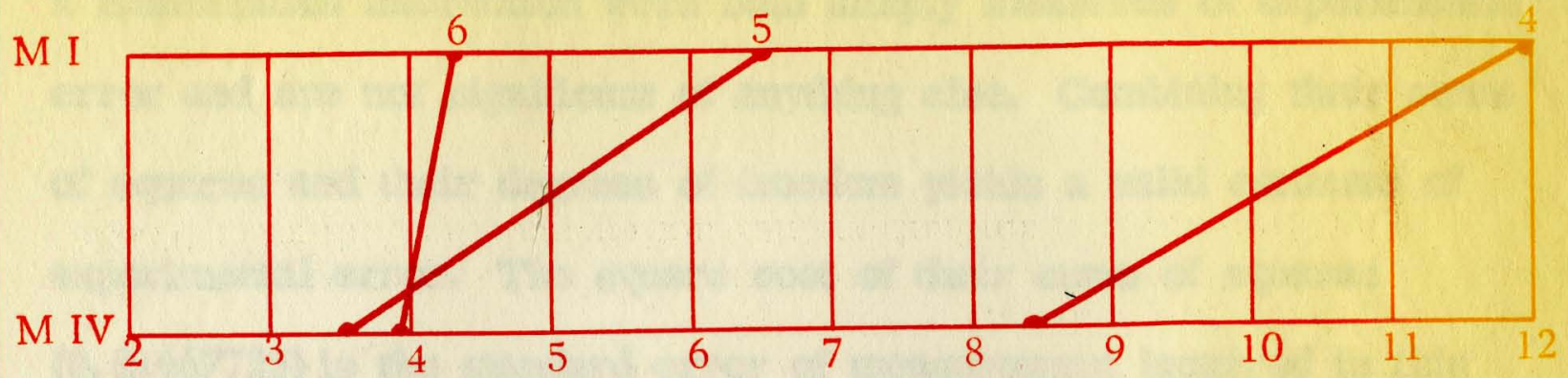

SUMS OF MEASUREMENTS

B. RIGHT SIDE - OCCLUSAL-GINGIVAL DIMENSION, INTERACTIONS BETWEEN TEETH AND EXAMINATIONS.

TEETH

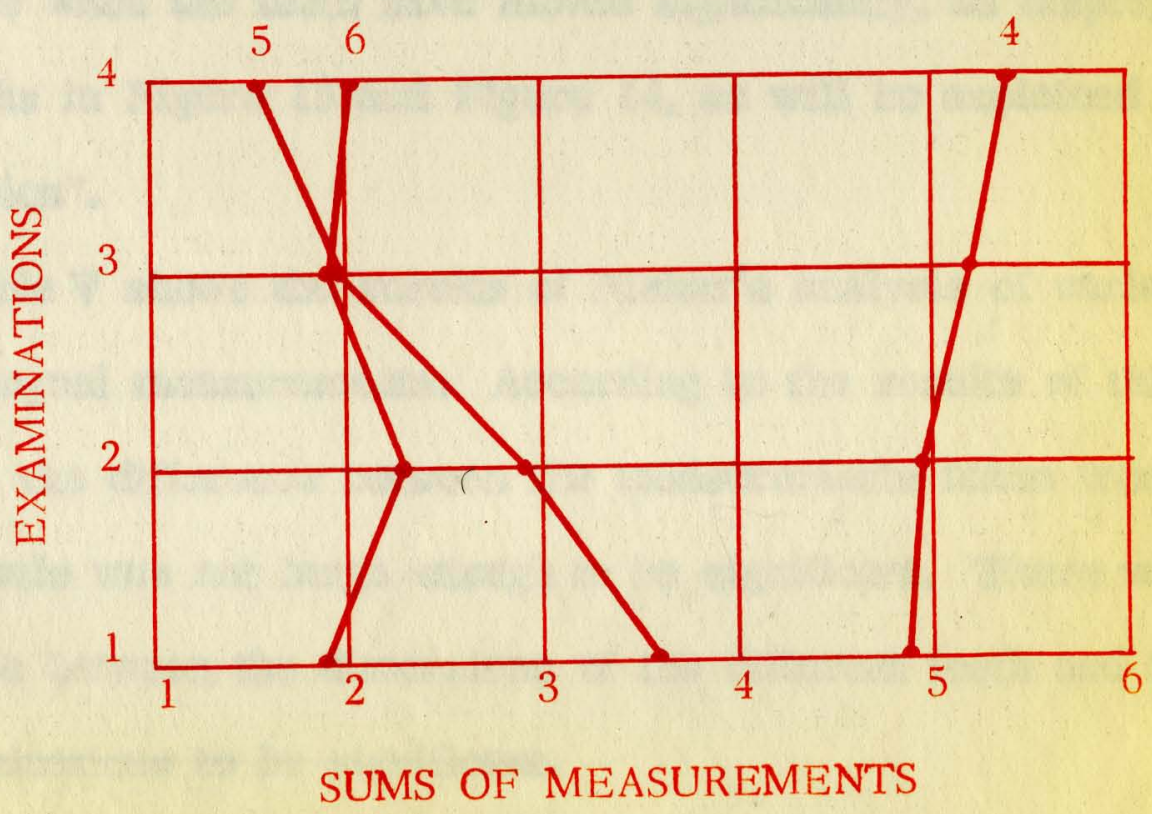

FIGURE 15 
- Examination interaction were hoth amply moasures of experimental error and are not stgnificant of anything else, Combininy their aums o: aquares and their dagrases of freedom yields a vald eatimate of experimental error. The gquare root of ther aums of squares (0.01667723) is the standard error of measurement incurred in thit work. This is 0.129 millmaters. The $99 \%$ confldence limits an the distribution of experimental errors are plus and minus $0.1197 \mathrm{~mm}$. This estimate of experimental error is used to determine the alsnilicance of the interactions montioned above. It la also used to determine whon the teeth have moved algnificantly, as displayed on the graphs in Figure 13 and Flgure 14,8 will be explained in the "Discusaion".

Table $\mathbf{V}$ showe the results of Fisher"s analysis of variance for buccal-lingual measurements. According to the resulta $\sigma$ this andysis, the difference between the meagurements taken from the two animals was not large enough to be aignificant. There was enough difference between the dimenalous of the diferem toeth and between the examinations to le significant.

The analyals reveals that the Animal Tooh interaction was 
ANALYSIS OF VARIANCE TABLE

RIGHT SIDE - BUCCAL-LINGUAL DIMENSION
D. F.
S. S.
M.S.
V Ratio

Animals

1

.0012916

.0012916

$<1$

N.S.

Teeth

2

13. 7463635

6. $8731817 \quad 21$

$19.00(.05)$

Exams

3

.9492166

$.3164055 \quad 23.48$

$9.12(.05)$

A $\times \mathrm{T}$

2

.6538509

.3269254

24. 1

$8.02(.01)$

A $\times E$

3

.0403158

.0134386

$<1$

N.S.

$\mathrm{T} \times \mathrm{E}$

6

$.785+238$

.1309039

9.66

$5.80(.01)$

A $\times$ T $\times$ E

6

.0815765

.0135960

Dupl icates

24

.0019735

.0000822

Total

$47 \quad 16.2600122$ 
large enough to be signilicant. A graph showing the significance between this two actor interaction is shown in Figure 16, A. The lack of paralleliam between the three lines representing the experimental teeth revesla the nature of the interaction between the two factors. If the three lines representing the experimental teeth were parallel to each other then this interaction simply would be a measure of experimental error and would not be significant of anything else.

The analyais shows that the Tooth $\times$ Examination interaction was large. A study o the graph of this interaction (Figure 16, B) shows the lack of parallelism between the line segments representing the experimental toeth. This lack of parallelism displays the exact type of interaction beween the two variasles of the experimental teoth and the four different examinations.

The sums of the squares of the two factor interaction of Animals and Examinations and the three factor interaction were small numbers. These, then, were aimply messures of experimental error and were not signilicant of anything else. Combining their sums of squares and their deyrees of treedom yields a valld 
A. RIGHT SIDE - BUCCAL-LINGUAL DIMENSION.

INTERACTION BETWEEN ANIMALS AND TEETH.

\section{TEETH}

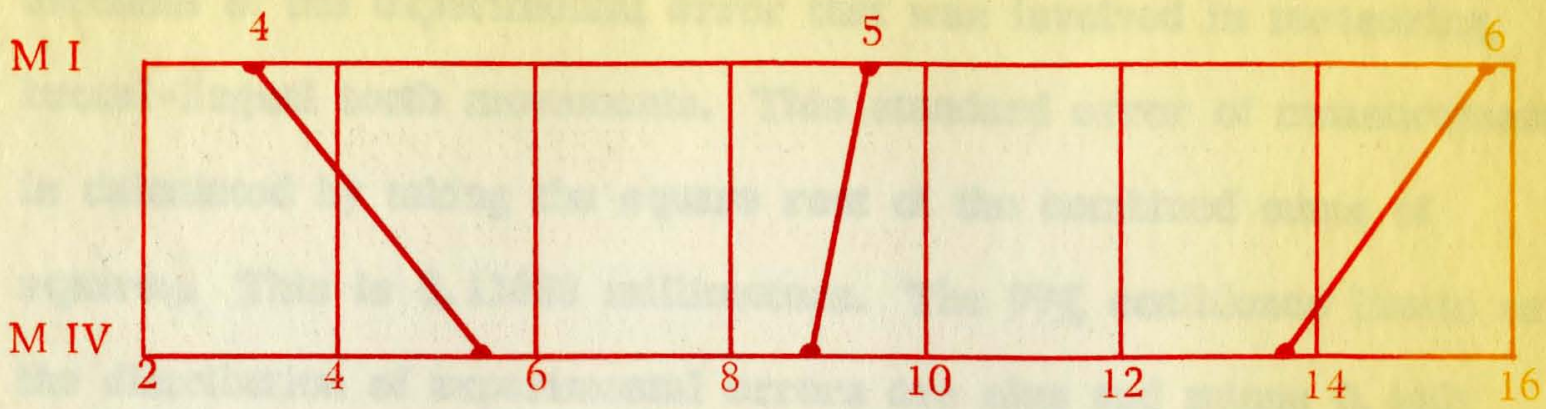

SUMS OF MEASUREMENTS

B. RIGHT SIDE - BUCCAL LINGUAL DIMENSION. INTERACTION BETWEEN TEETH AND EXAMINATIONS.

TEETH

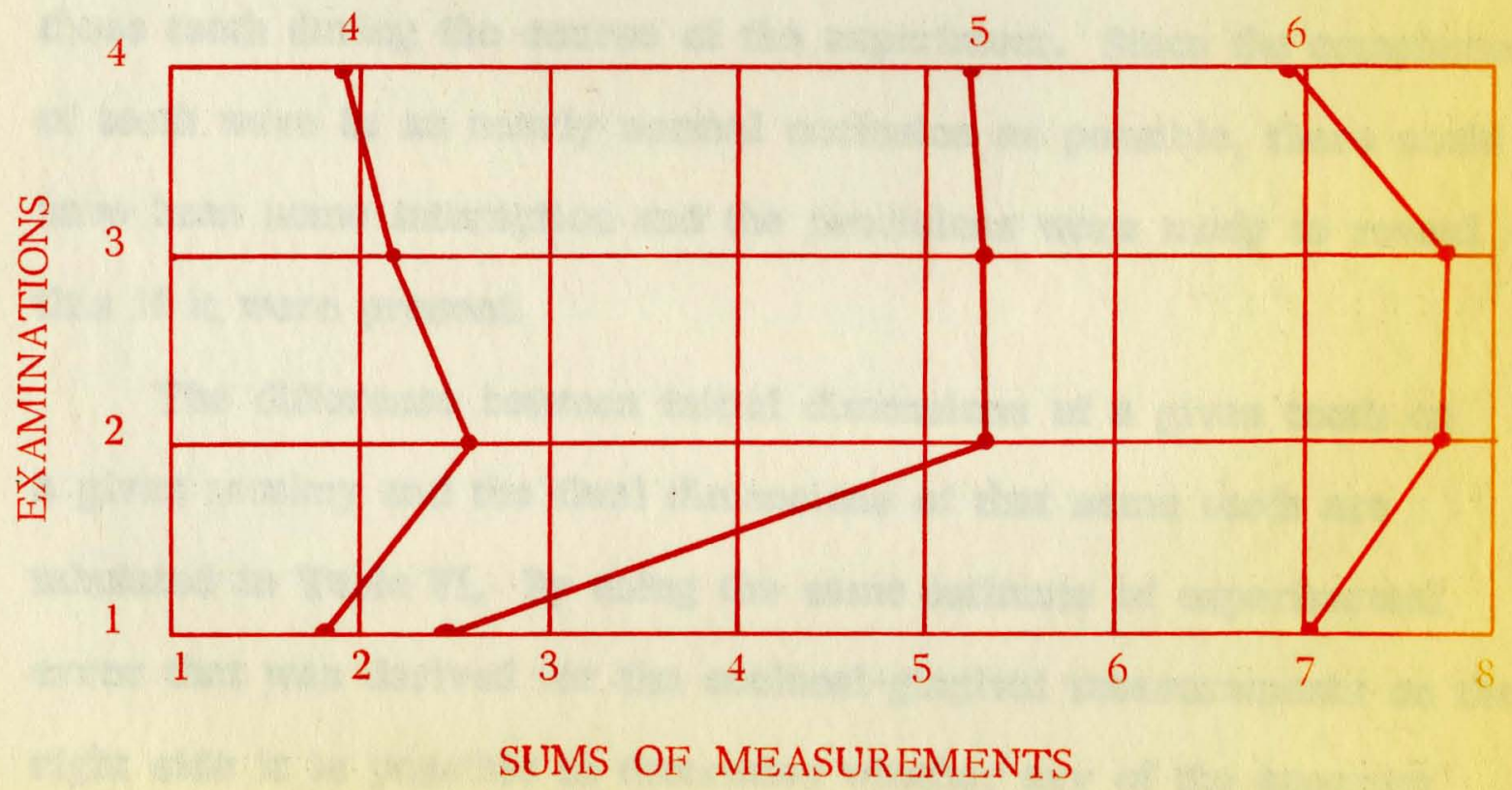

FIGURE 16 
astimate of the axperimental error that was involvod in measuring buccal-lingul tooth movements. This atandard sror of measurement Is calculated by taking the square root of the combined sums of squares. This is 0.1163 millimeters. The 998 conididence limits on the diatribution of experimental errors are plus and minus 0 . 101 millimaters.

C. Assessing Tooth Movement of the Refierence Teeth

The left aide of each monkey was reberved for a relerence set of measurementw to hind whether there was any movement of these teeth during the course of the experiment. Since the complement of tech were in as nearly normal occlusion as possible, there could have been some interaction and the provisions were made to reveal this if it were present.

The difterence tetween initial dimonsions of given tocth on a given monkey and the rinal dimeasions of that same tooth are cabulated in Table VI. By using the same eatimate of experimental orror that was derived or the ccclusal-gingival meanuremonts on the risht aide it possible to determine whether any of the apparent changes in tocth position were large enough to be outside the limits 


\section{TABLE OF DIFFERENCES}

\section{OCCLUSAL-GINGI VAL DI MENSION \\ REFERENCE SIDE TEETH}

$$
\underline{4}
$$

Monkey M I

Monkey M IV
$-.162 \mathrm{~mm}$.

$-.038 \mathrm{~mm}$. $\underline{5}$

$-.357 \mathrm{~mm}$.

$-.071 \mathrm{~mm}$. $\underline{6}$

$-.264 \mathrm{~mm}$.

$-.178 \mathrm{~mm}$.

Decrease in dimension means intrusion.

\section{BUCCAL-LINGUAL DIMENSION}

REFERENCE SIDE TEETH

$\underline{4}$

Monkey M I

Monkey M IV

Decrease in dimension means lingual tipping.

Difference - The last average measurement minus the first average measurement.
$-.377 \mathrm{~mm}$.

$-.051 \mathrm{~mm}$.
$-.371 \mathrm{~mm}$.

$-.221 \mathrm{~mm}$. 
ot exparimental error.

The occlusal-ginglval dimenalon of tooth on Monkey 1 appeared to change aignificantly. Also the buccal-lingual dimensions on this same tooth appoared to change stgnificanty and this same dimension of tooth in the same monkey changed sifnificanty. These apparent changes will be discussed later.

D. Tiswe Changes Caused by an Experimental Extruaive Force: The transwerse pecticas taken near the apicas of the maxillaxy right Aret premolar showed the roots to be closer to the buccal than to the Ingual cribriform plate. The succal alde of these rocts was the side of compression. Numerous Howship'a lacuma are seen in this area containing osteoclasts. It may assumed rom the preaence of these large multimucleated cells that root and alveolax bone resorption are occurring in these areas. Near the apices on the compresion side of the buccal roots, small areus of cementum resorption are seen. Fibroblasts normally geen in the perlodontal Ifgament are seen in abundance around these area of resorption. As the transverse sections approached the area o the root trifurcation, little change in the normal width of the periodontal apace is apparent. 
Transverse sections near the alveolar crest reveal lingual displacement of the tooth rook. The buccal aspect of the cri riform plate is the side of tension whereas the lingual surface is the side of compression. The cellular changes occurring in these sections above centrold are less apparent than those below the tipping center. These indings are schematically shown in Figure 17. On the tension side, the side of bone formation. pink staining osteoid tissue is lining the cribriform plate. Osteoklasts with their dark staining cytoplasm are lining the surfaces of the coteotd. This indicates bone was being laid down in an eftort to maintain desired periodontal space width.

The transverse sections of the furst permanent molar teveal little evidence of tension or compression gides, but rather a generallzed increase in the width of the periodontal space. This increase in width of the periodontal space was accomplished by the process of direct bone resorption on all aurfaces of the alveolar socket. Cementum resorption is present in the transverse section in the area of the root trifurcation and various other surfaces of the roots (Figure 22, B). This was expocted because this tooth was subject to jiggling forces. The mesial-distal sagittal sections o? 
A. DISTAL ASPECT OF EXPERIMENTAL TEETH INDICATING DIRECTION OF TIPPING

4 AND 6

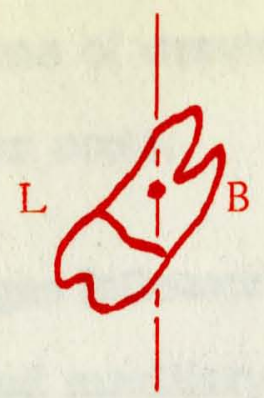

5

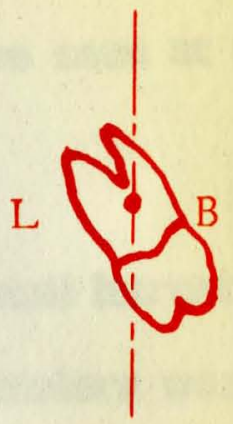

B. ROOT RELATION TO ALVEOLUS (TRANSVERSE SECTIONS)

4

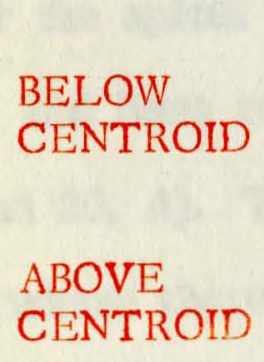

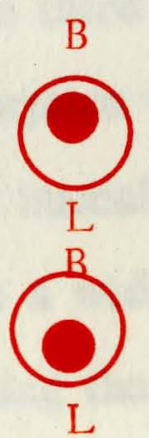

5

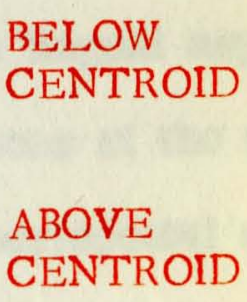
CENTROID

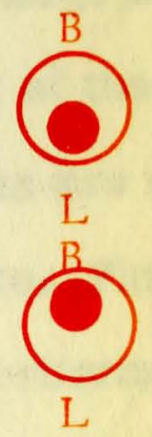

C. SYMBOLS

B - BUCCAL

L - LINGUAL

4 - MAXILLARY RIGHT FIRST PREMOLAR

5 - MAXILLARY RIGHT SECOND PREMOLAR

6 - MAXILLARY RIGHT FIRST MOLAR 
the Arst permanent molar revealed a widening of the periodontal apace (Figure 18). Cementum resorption is seen at the molar trifurcation as well as bone reaorption of the interradicular alveolar crust. Small aroas of cementum resorption are seen at the apical ends of the molar roots.

2. Tissue Changer Influenced by an Experimental Intrusive Force: The intruded maxillary right wecond premolars were leings moved away irom the occlusal plane, (depressed). Traneverge sections near the apical one third of the roots reveal large areass of cementum and bone resorption on the lingual aspect of the roots (Pigure 19 and $20, A$ ). The buccal surfaces of the rocts are the tension side where there is a widened periodontal space. Pink staining osteoid is aeen lining the interface of the cribriform plate on the twasion side, (Flgure 20, B). As the transverse sections approach the middle one third of the rocts, the width of the periodontal space becomes normal. Transverse sections near the alveolar crest reveal buccal diaplacement of the premolar rooks. The buccal sicis now becomss the side of compression and the lin wal 


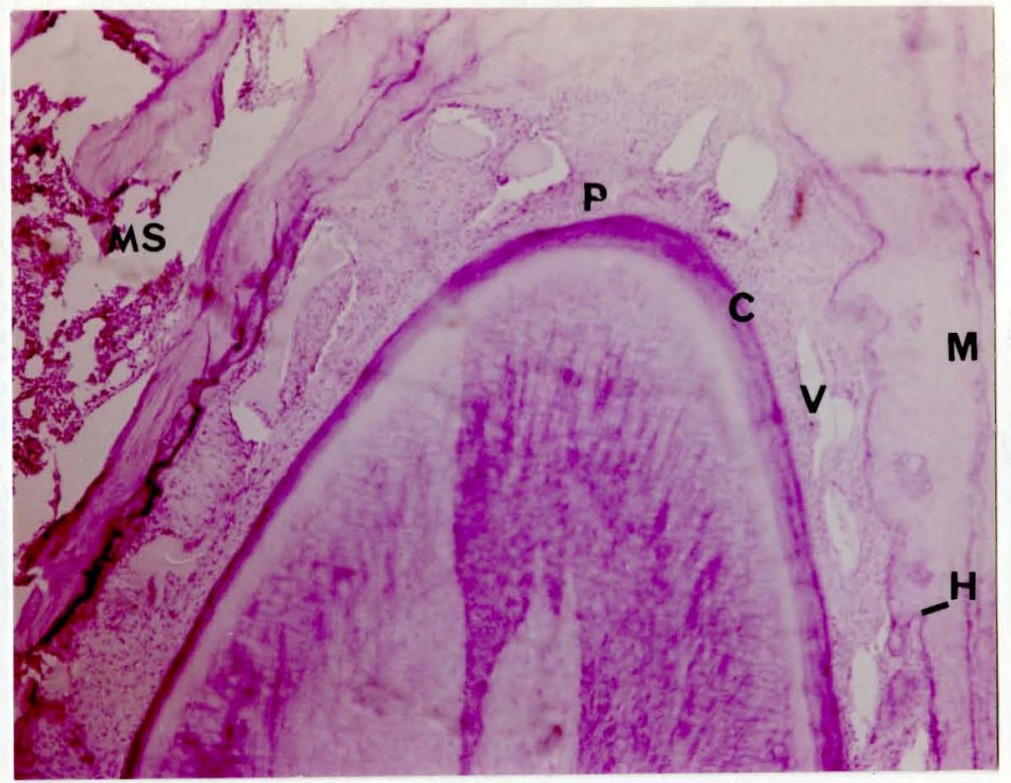

MESIAL BUCCAL ROOT APBX

OF THE MAXILLARY RIGHT FIRST PBRMANENT MOLAR SHOWING A WIDENED PERIODONTAL SPACE (9X)

M MBSTAL

C CEMENTUM

D DENTIN

P WIDENED PERIODONTAL SPACE
H HOWSHIP'S LACUNAE

MS MEDULLARY SPACB

V BL.OOD VBSSELS

B AREAS OF DIRECT BONB RESORPTION

FIGURE 18

BXPBRMMENTALLY BXTRUDED TOOTH, SAGTTAL SECTION 


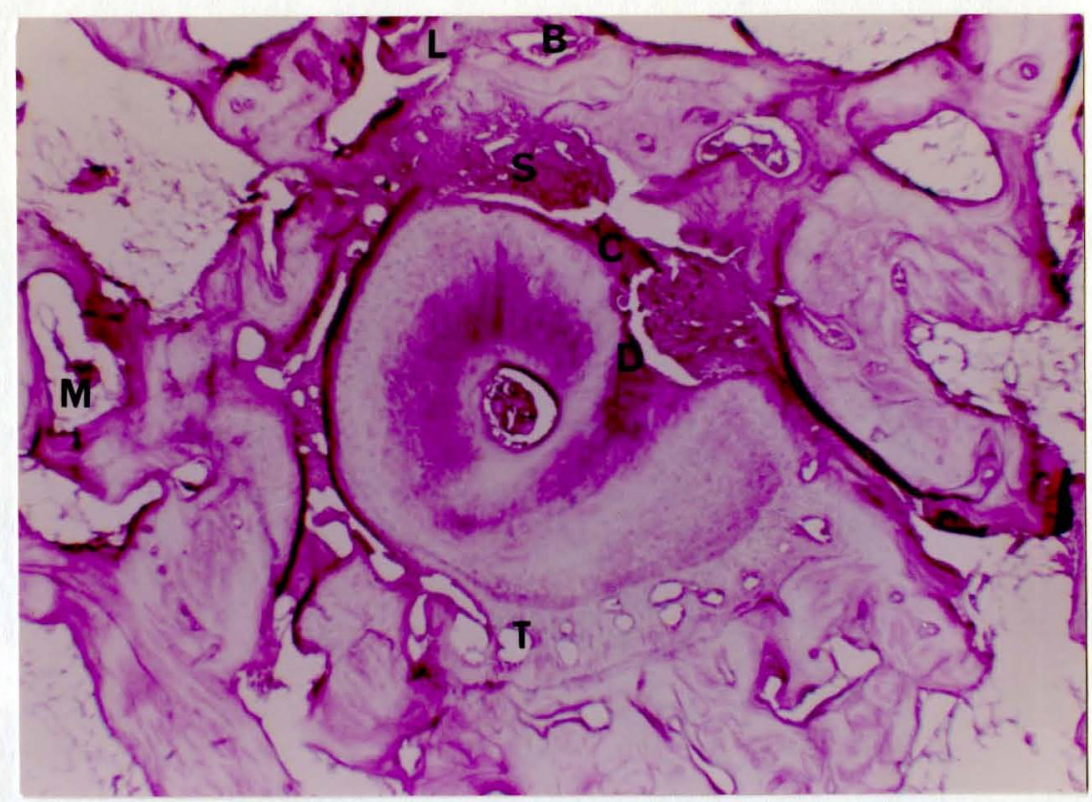

TRANSVERSR SBCTION NBAR THE APEX

OF THE MAXTLLARY RIGHT SECOND PRBMOLAR (6.3X)

THE BXPERIMENTALLY INTRUDED TOOTH

NOTE THE LINGUAL, DISPLACEMENT OF THE ROOT APBX ESTABLISHING A BUCCAL TENSION SIDE AND LINGUAL COMPRESSION SWDE.

L LNOUAL

M MESIAL.

C CEMBNTAL RESORPTION

D DENTINAL RESORPTION
S SIDE OF COMPRESSION

T TENSION SIDE, THE STDB OF BONE FORMATION

$B$ BONE RESORPTION, THB SIDE OF DIRECT BONE RESORPTION 


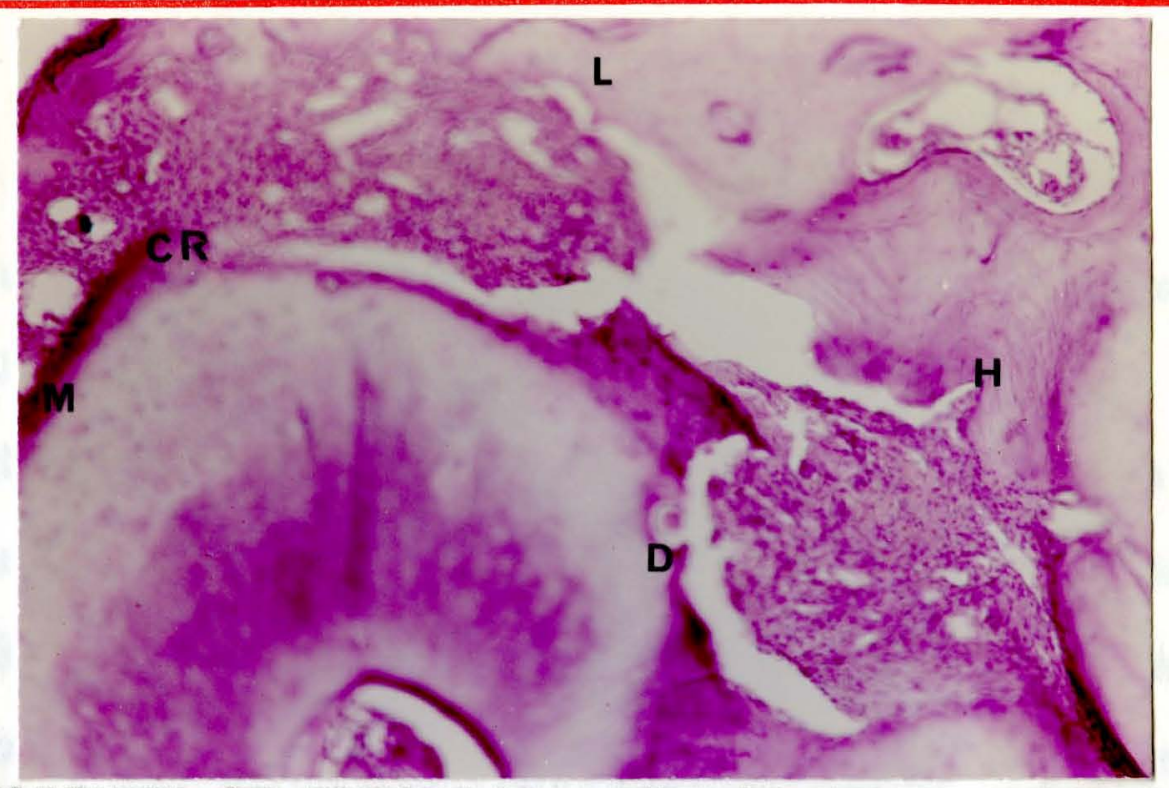

A. HIGH POWBR OF FIGURB 19 SIDE OF COMPRESSION (14.4X)

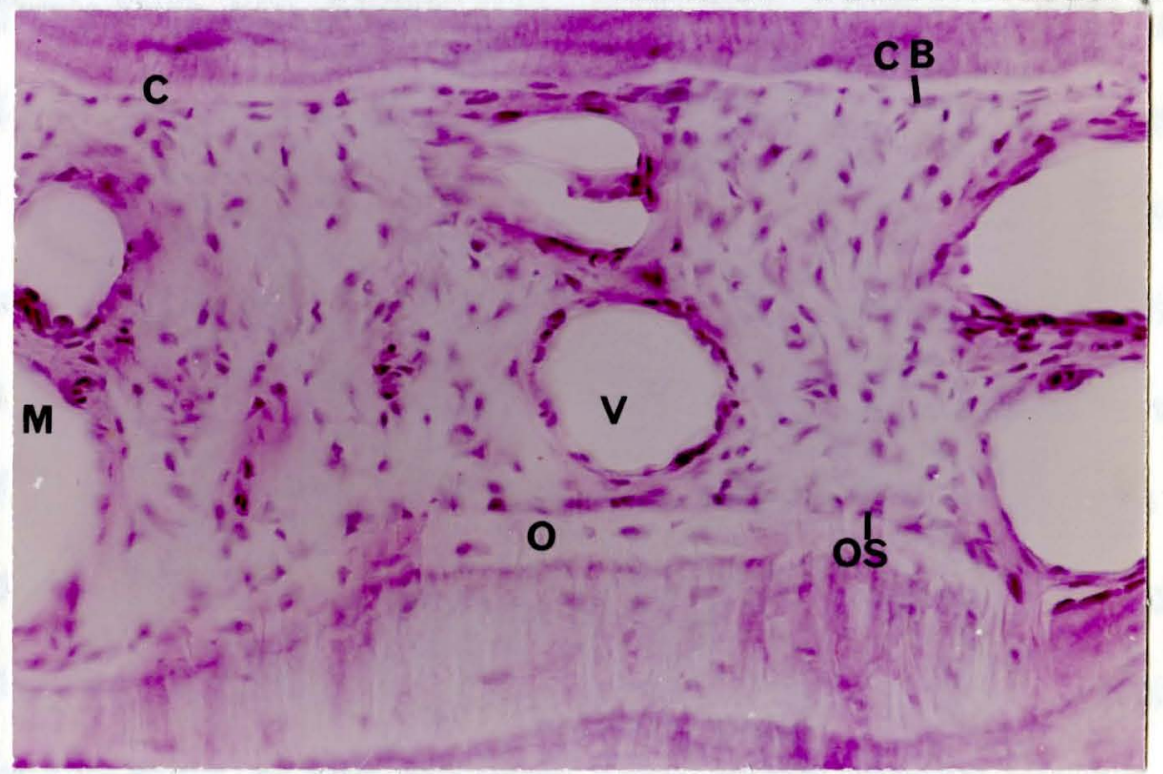

B. HGH POWER OF FIGURB 19 TENSION SIDE $(56.25 \times)$

L LINGUAL

M MBSIAL

CR CBMBNTAL RESORPTION

H HOWSHTP'S LACUNAB

D DENTINAL RESORPTION

\section{$\checkmark \quad$ BLOOD VESSELS \\ O OSTEOTD}

OS OSTEOBLASTS

C CBMENTOID

CB CBMENTOBL.ASTS 
the alde of tension. The tasue etunges cocurring in the transverse bection above centroid are less obvious.

Sagittal acetions of the second premolax show cementum rescrption in the aras of the root apleas and the intersuriaces of the apical foramin (Figure 21). There is a generallzed narrowing of the periofiantal apace indicating the tooth is being forced into its acket. Cementum and dentin resorption are present at the root trifurcation (Figure 22, A). Resorption is more apparent around the aplees of the buccal roots than it is on the larger lingual rock. The entire mosial suriace of the cribriform plate in the mosial-distal section is undargaing direct bone regorption while the ontre distal surtace of the plate is covered with a layer of ostedd (Figure 23). The impression may be gained fron this that the second promolar 1s baing tranelated mestally. Careitul obsorvation of the sagittal sections in the area of the alveolar bony crest reveal crestal bone resorption.

F. Tisue Changes Around the Reforence Teath:

The marllary xight canine and second permanent molar were the toeth used to orient the maxlliery right transfer units. These 


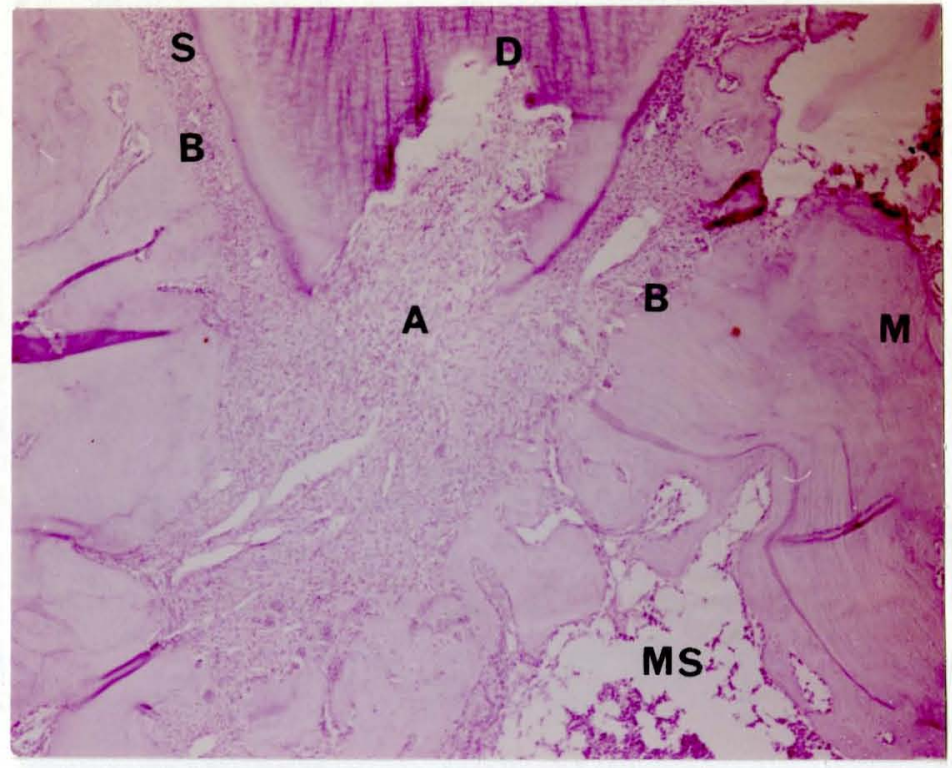

MESIAL BUCCAL ROOT APEX OF THE MAXILLARY SECOND PREMOLAR. THE EXPERMMENTALLY INTRUDED TOOTH WITH AREAS OF APICAL AND DENTWNAL RESORPTION (OX)

M MESIAL

D DENTINAL RESORPTION INSIDE THE PULP CANAL

A APICAL FORAMEN

B AREA OR FRONTAL ALVEOLAR BONE RBSORPTION

S AREA OF NARROWING OF THE PERIODONTAL SPACE

MS MEDULLARY SPACB

FIGURE 21

BXPERIMENTALLY INTRUDED TOOTH, SAGTTTAL SECTION 


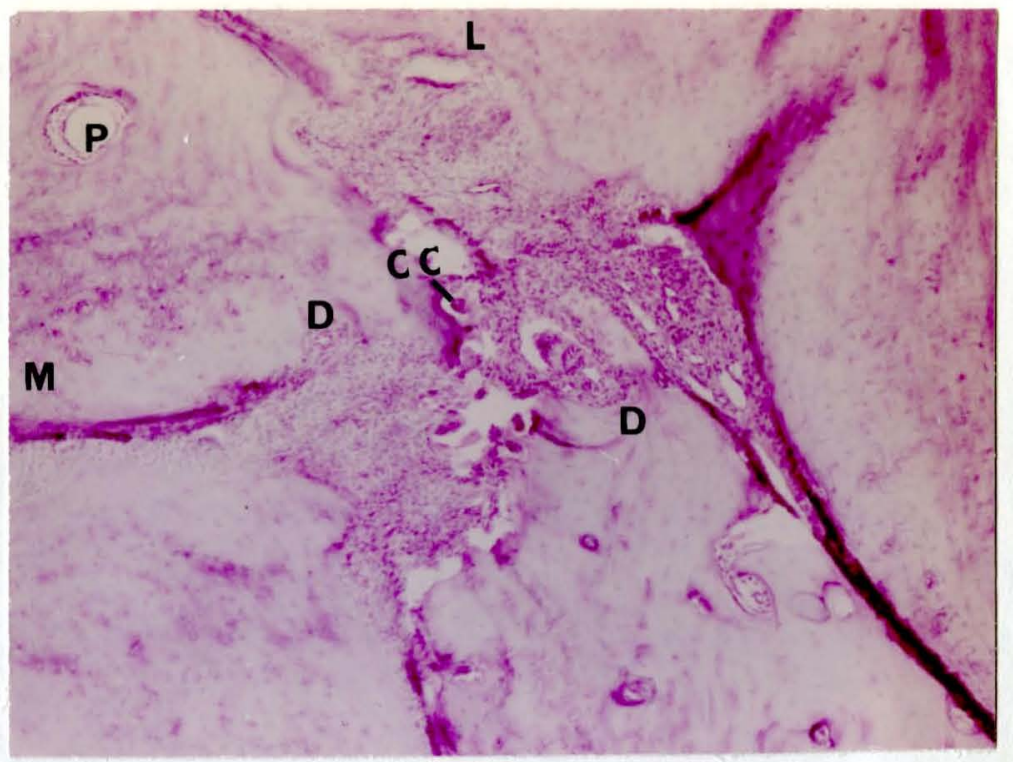

A. THE BXPERMENTALLY DNTRUDD TOOTH SHOWING DENTINAL. RESORPTION $\mathbb{N}$ THE AREA OF THE ROOT TRIFURCATION (9X)

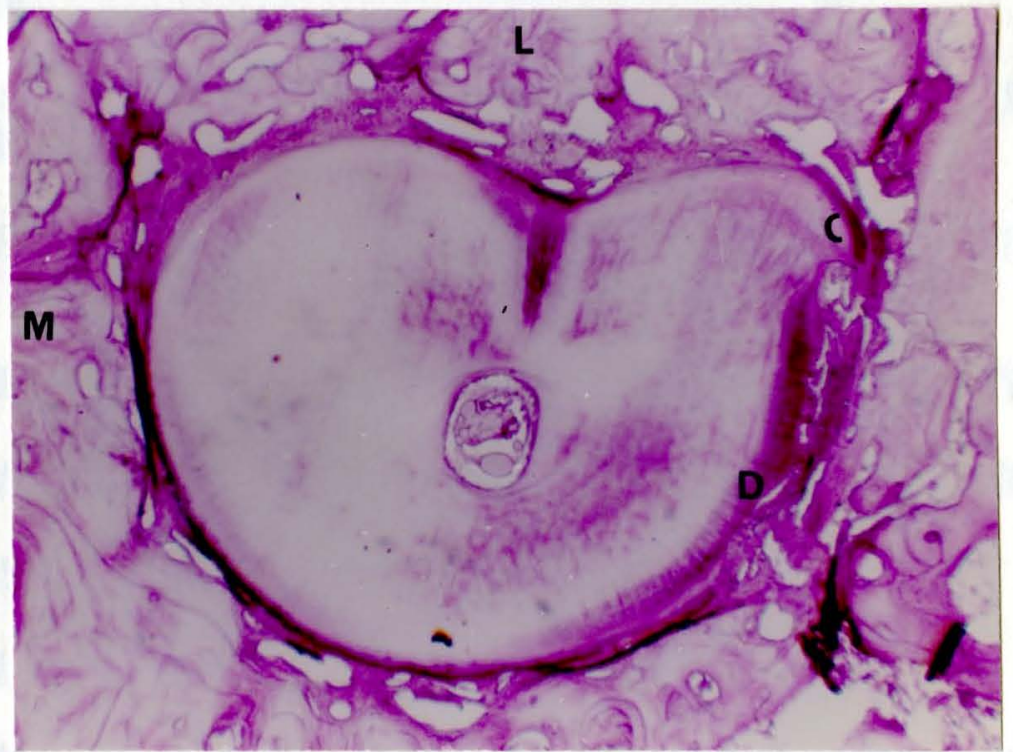

B. TRANSVERSE SBCTION THROUGH MIDDLE ONE THRD OF THE LINGUAL ROOT OF THE MAXTLLARY RIGHT FIRST PBRMANBNT MOLAR (6.3X)

L LNGUAL

M MESIAL

D DENTINAL RESORPTION
CC CEMENTOCLAST

P PULP CANAL

C CEMIENTUM RESORPTION 


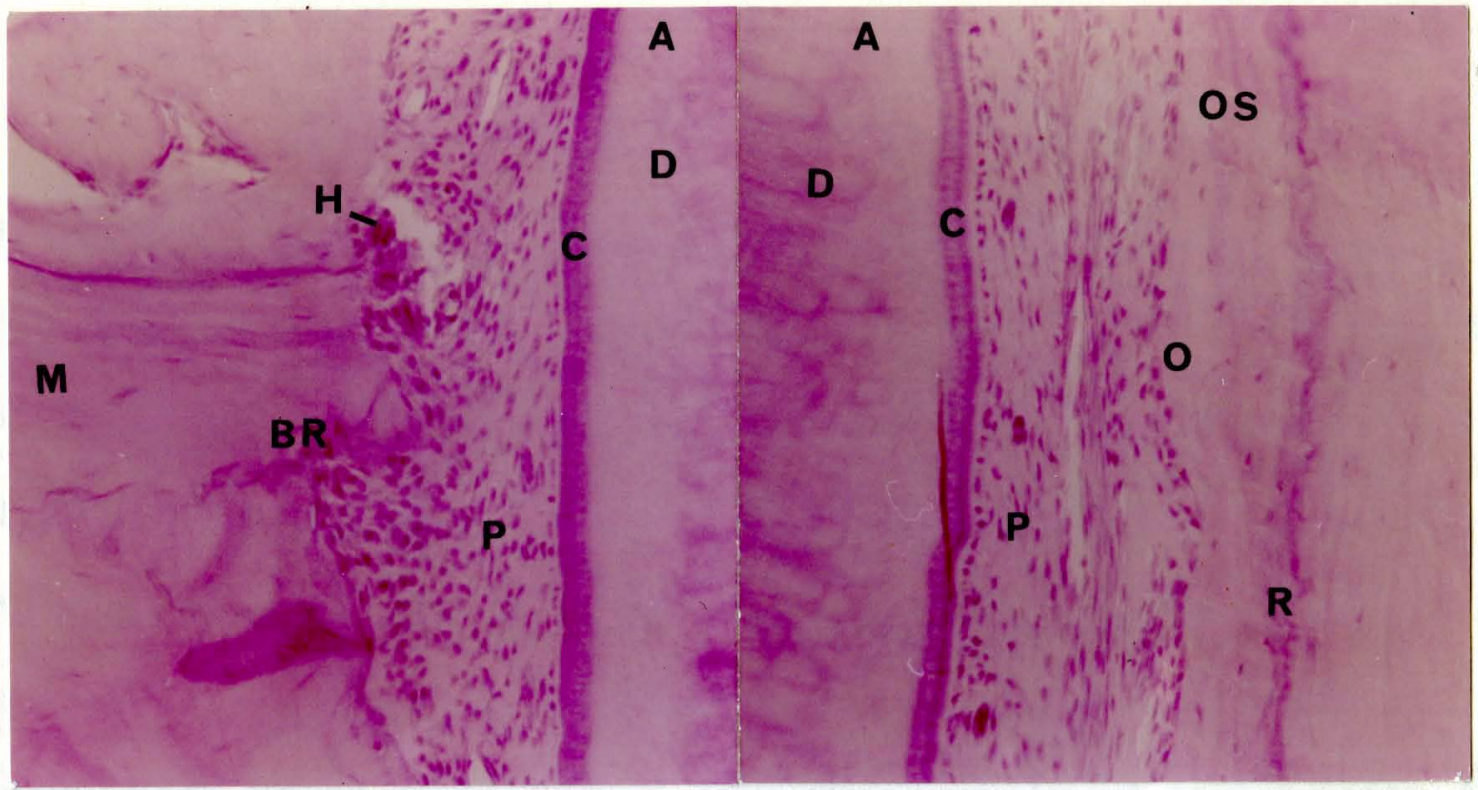

A.

B.

A. MESIAL SURPACE OF THE EXPERIMENTALLY INTRUDED TOOTH'S MESLL BUCCAL ROOT (22.5X)

B. DISTAL SURPACE OF THE EXPERMENTALLY INTRUDED TOOTH'S DISTAL BUCCAL ROOT (22.5X)

BOTH PHOTOMICROGRAMS ARE FROM THE SAME SAGITTAL SBCTION AND SHOW A RERRESENTATTVE SECTION OF THE ENTIRE MESIAL. OR DISTAL SURFACES, THIS TOOTH WAS APPARBNTLY TRANSLATING MESTALLY.

$\begin{array}{llll}\text { M } & \text { MESLAL } & \text { BR } & \text { ARBA OF FRONTAL BONE RESORPTION } \\ \text { A } & \text { APICAL END } & \text { H } & \text { HOWSHT'S LACUNAE WITH OSTEOCLASTS } \\ \text { C } & \text { CEMBNTUM } & \text { P } & \text { PERIODONTAL LIGAMENT } \\ \text { D } & \text { DENTTN } & \text { OS } & \text { OSTEOBLASTS } \\ \text { O } & \text { OSTEOID } & \mathbb{R} & \text { REVERSAL LNIS }\end{array}$


teath wore adjacent to the teath that were under the influence of the orthodontlc appliance. When comparing the perfodontal environment of these teeth wh the maxillary lot canine and second permsnent molar, no signiflcant collular changes are apparent. A coastant widh of the perlociantal apece is seen in the transverse sections of the refersnce toeth totcthot with a large number of stellate

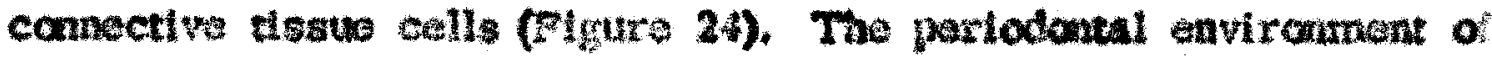
the reference teeth in the sagital sections shows no apparem abormal collular changes (Figure 25). 


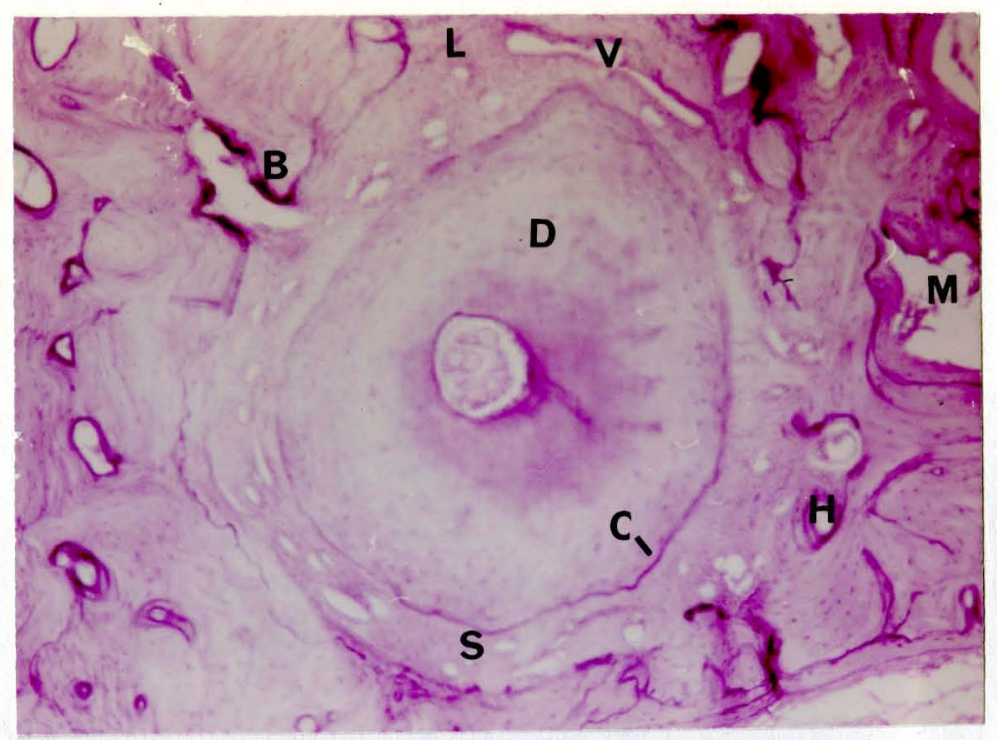

A. MAXILLARY LEFT FIRST PREMOLAR, APICAL RECION OF THE DISTAL BUCCAL ROO' CHARACTBRIZNG A NORMAL PERIODONTAL BNVIRONMIENT (OX)

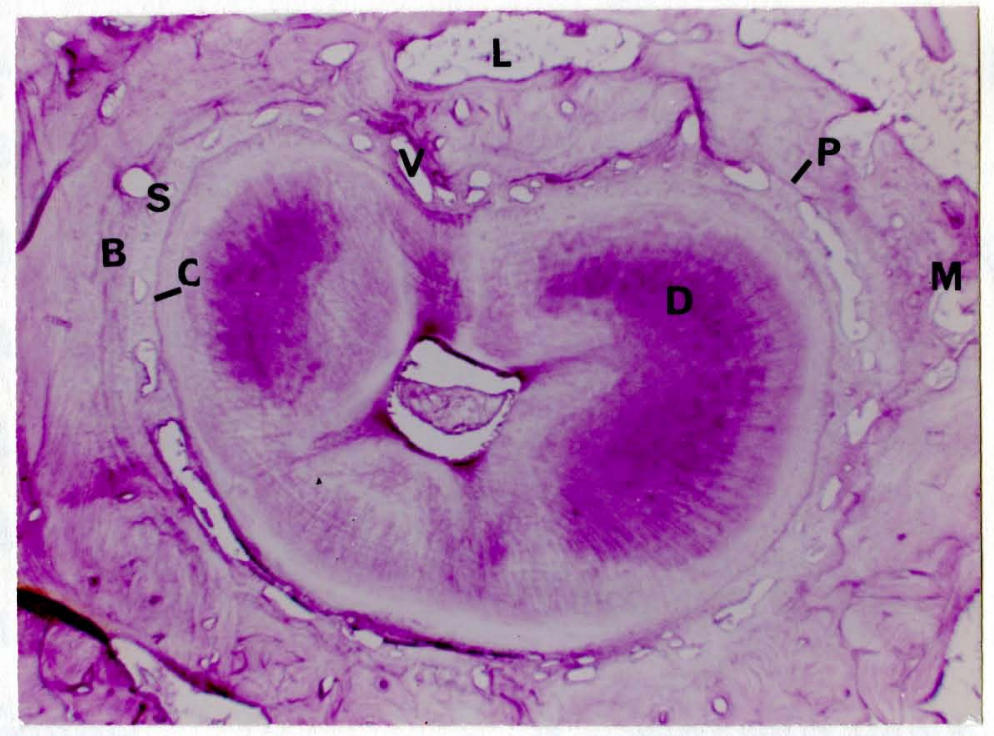

B. MAXILLARY LEFT MTST PERMANBNT MOLAR, MIDDLE OF THE LINGUAL, ROOT (4.95X). NORMAL PERIODONTAL ENVIRONMENT

L. LNGUAL M MESIAL.

D DENTIN

P CRIBRIFORM PLATE

B MATURE LAMIBLLATED BONE
C CBMENTUM

S PBRIODONTAL SPACB

V BLOOD VRSSRLS

H MAVBRSTAN SYSTBM AND CANAL

FIGURB 24

RBFBRENCE TEISTH, TRANSVERSE SBCTONS 


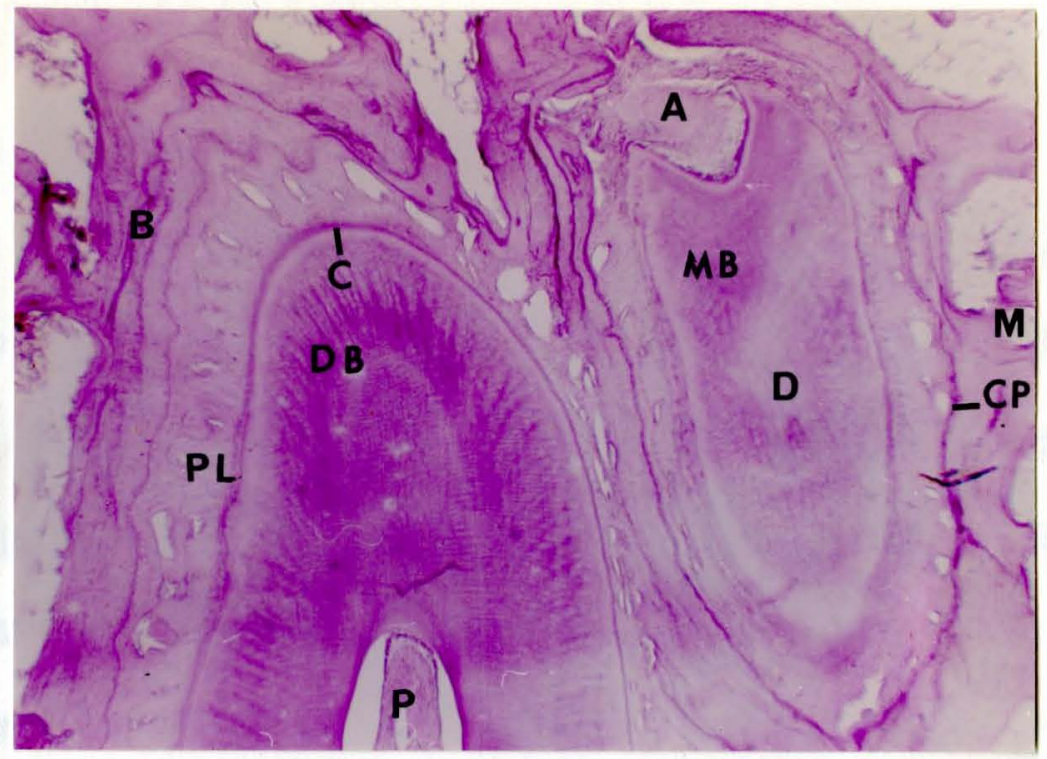

MAXILLARY LEET PIRST PREMOLAR, SAGITTAL SBCTON THROUCH THE BUCCAL ROOTS (4. 95X)

THS SECTON IS IROM TIE RETBREWCE SWDE AND SWOWS TIE NORMAL PERIODONTAL, ENVIROMNGST.

DB DISTAL BUCCAL, ROOK

MB MESLAL, BUCCAL, ROOT

M MESLAL

P PULP CANAL

PL PERIODONTAL LIGANIBNT
C CBMENTUM

D DENTWN

CP CRIBRTFORM PLATE

B MATURE LAMELLATED BONE A OPISN ROOT APBX

\section{FICURB 25}

REFERENCE TEIST, SAGTTTAL SECTON 


\section{CHAPTER V}

\section{DSCUSsion}

In any attompt to quantitate the magnitude of physical movements

of teth in spece with histologic changes in bone it is necessary to know very preciaely the diroction and the amount tecth move when subjected to spechacally designed orthodontic iorces. Such a biophyoical asesesment requires a precies instrument for the physical asgesament of tooth movements in space.

This reacarch deals with the developmant and use of such an instrument. Although the detalls of the uee of thit inatrument are fully described in the section on methode and materials, the basic underlying theories and concepts for its development need now to be discussed if its real value to this reguarch is to be understood.

The methods of producing movements of the experimental testh In this study were mathods well understod; the means of measuring the positions of these axperimental teeth were new onea developed for this experimont. Althowh other investigators have amployed conventional, direct mothods of measurements whin the locations o teeth had to be established, the decision in this case was to use an 
indirect method that carried a risk of Leing both inaccurate and imprecise because it tad geveral ateps in its procedure and lecause it was untried. The proposed method required the use of some conventional dental techniques and required the construction and utilization of a now measuring instrument and special mounting Ustures. Because a the imnovations, it was deomed very important to study the method Arst and to determine ite precision and reliablity. After the special instrumenta were built and the cochaiqua of makings the transier units was outablished, an experiment was deaigned and conducted to learn the prectaton of the maasuring portion of the procedure. The cutcome of this experimnt established the leaslility o. the indirect method of measuring and gave some estimate of the arrore that might le encountered in making these measurements on the transler unita. Later the experimental data ware analyzed to give the mosure oi the arrors Incurred in the whole procedure and these estimates of the erro variance were used to determine which neasurements had changed significantly as a result of the experimental treatment.

All of these studies on the accuracy and precision of this mothod 
were to loarn whether the method was accoptathe Irom the atandpoints $o$ teagibility and rallablity. The somewhat slatorate investigation or these appets of the new method has developod proot that the mathod hat good capalilitios but that it needa to we rofned and also extended to the meking of monsurremonts in ocher directicns.

In Chapter II, "Methode and Materials", tho statoment was mads that the special hature used in gettiny the transter units into their carrers was ono ualng a combimation of point, line, and a plane. This physical prineiple is not now, yet its application to arthodontics as demontrated in thi restarch is aryinal. The phystcal principle employs a hypathetical triad of threa points which rorms a plane in space. These points arve to accept three points on an object, roproducilly ortanding the olyect to the plane in spacs. Thus the combination o point, a line, and a plane will always aerve to reproduclbly orient another plane in space when that plane can be identified by hypothetical triad of throe points.

The use of this new mothod to meastre changes in tooth position in this regatich has a twolold purpose. Wiret, it permits us to neasure within an erro: of plus or mimus $0.4 \mathrm{~mm}$. the 
amount teeth will move in relation to given teterence teeth which are not engaged in the force atom being studied. Second, it sives us accurate physical criteria sor measuring histologic changes resulting trom specific force gystoms. Thus, in orect, the phyaical indings help to rainforce hiologlc observations bes histologically and abservations get specific meaning when they can be supported by massurement of the physical changes ot the teath in spece.

In looking the graphs in Figures 13 and 1 , it appars that certain obvious crends in toch mowement are establiahed by some Ines while chere are inditerent. To assess the algulicance of the trends, the point of a line was compared to the last by applying a statistical test to the difterences botween these two points. The test would ascortain whother any indican change in tooth position had occurred. The aimplest statistical test for this purpose is Student" "t" test. When this teot was applied to the diferent teath repreaented by the Ines in the rraphs ouly two ou of $1 \times$ in each figure were glonicant at the 0.05 level of proxability. This means that two Ines represented actual changes in tooth position and that these ehanges would be due to oxperimental tooh movement rather than 
chance in ninety-five out of one hundred times. From this test it could be atated that the second premolar in both monkey was intruded and tipped buccally.

What is not immediately ovident from the above statement is the fact that this experimantal intrusion can be partly accounted or by the osservation that as the maxillary premolar is tpped huccally. the tip of the succal cusp moves inieriorly. Thus a pure tipping movement would show a degree of intrueion when the occlusoginglval tooth measuremonte were recorded. It must not be overlooked, however, that the histologic sectiona show areas of cementum and dentin resorption at the rock apices and trifurcation as well as direct bone regorption of the cribtitorb plate, Indicating definite intrusion of the premolar tooth.

In any consideration of orthodontic forces, whether they are applied to one tooth ox to several teeth, onte cannot lose sight of the fact that there is wo such thing as a single orce; accompanying: the working force there is always a reactive lorce (Nowton's Third Law), The lorce system described in this research was deaigned to intrude or depress a maxillary socond premolar tooth. In the application of 
this sorce yotem the maxillary urat molar and hrst premolar, Loting the anchor teeth, ghared the load of the reactive force. It might be expected that they would extrude and tip lingually. Yot whon the actul movemante of these teeth were assessed by the phytcal means, it was lound that the anchor teeth did not move beyond the limits of statiatical algnificance (Figures 13 and 14). This leads ono to aak why? it Is likely the roal answer lies In the fact the ceclugion of the antagonist toeth in the mandible drove the teech hack into tho socket very time tho jaws were closed. Thus. it must be assumed the anchor teeth camo under the influence of two forcest the extruaive force of the appliance and the intrusive lorce of occlusion. This caused those teeth to Jigels in their alveolar process.

Constdering anchor teeth, the error is often made that these teeth do not move. If we ware to take the physical moasurements in this exporiment on thel lace value (seo Figuro 13 and 1.4) we might well draw the same conclusion. Yet ince the reactive force (deacribed in Newton's Thrd Iaw) camnct le dinied, we can loglcally asaume this secming anchorage otablity is the rasult of the intrusive 
forces caused by the forces of occlusion with the teeth in the opyouing jaw. This in a plausible hypothosis.

Some support of this hypothesis is found in the obervations of Reitan, 1951, and in the histologic data otained in this experiment. Figures 18 and 22 , B reveal that the anchor teeth experienced jiggling. In effect the histologic olservations made in this resoarch are nearly Identical to those of Went, Jarabak, and Orban (1958). Since the lorce systems used by these investigator were directed diferently than those in this experiment it was expected that there would be some differences seen in the histolofic tissue picture. Yet since thase differences were so amall it is difficult to difierentate intrugive and extrustve jiggling from lateral $11 \mathrm{gs} l i n$.

In Chapter III an entire section was devoted to deslgning and analyzing the force sytom used in this experiment. This rorce system was designed to tip the second premolar buccally and intrude it. This combination o tooth movemants was verified by physical means o: ascessment. This was done by measuring the four transep units. The depressing lorce syatem intruded the experimental teth a bout $0.2 \mathrm{~mm}$. each ten days of the experiment. This means the topth was depressed approximataly $0.6 \mathrm{~mm}$, for the thirty days of the 
experiment. These teeth were also tipped kuccally as expected because the intrusive force was not acting along the central axis of the premolar, but rather lateral to it. It mut be emphasized that since the bracket was on the buccal surface of the tooth a moment was devaloped. Because of this moment there could be no purely intrugive Sorce. Consequently this tipping and intruaicn were combined. The amount of buccal tipping of the second premolar of Monkey I was approximately $0,+\mathrm{mm}$, while tor Mankey IV it was over $0.7 \mathrm{~mm}$. The histologic indings urther document that buccal tipping did Indeed occur. Rspecielly was this true in the transverse histologic sections. Sectione near the roct apices show the roct to be tipped into the lingual cribriform plate. This ungual aurface was the aide o compression. Hore cementum and dentin resorption did occur (bee Figures 19 and $20, A)$. As the trangverse bections neared the tipping center, a constant width of the periodontal space it aeen. This was expected secause there is very little movement at the tipping center. Below this center, the root was tipped toward the Wuccal cribriform plate.

Sagittal sections of the second premolar which was intruded 
and tipped experimentally reveal large areas of resorption of cementum and dentin at the roo apices and root trifurcations (FIgures 21 and 22, $A$ ).

This obervation raiged the question of whether light lorces, such as those used in this experiment, applled continuouly ahould to used clinically. Some queations will need to be answered by luture research (1) WhI intermittent intrusive forces show less damage to the dento-periodontal environment (2) Is it the magnitude, the direction, or the point of application that causes the root resorption (3) Cian a tocth possibly be orthodontically intruded without root resorption?

The modus operandi of this resorption process is intereating. Numerous fibroblagt were seen in the immodiate areas of rasorption. Osteoclasts in Howship's lacunwe were seen in the immediate areas of the alveolar fundus and in the interradicular crests. All of thege cells point to the fact that this alveolar remodeling was boing accompliahed by direct reaorption.

Since boas remodeling is done moatly by direct resorption it can hardly tye sald that the remodeling induced by this continuous 
horce system is truly destructive. Instead, it seems more accurate to assume that aince the damage was very slight, repair will take place leaving virtually no permanent acars on the roots.

To further confirm the direction in which this tooth moved, we need coly examine the mesial and distal alveolar crests. The crost approaching the root surface area of the maxillary second premolar was distinetly concave. This was due to the lact that the transcoptal ibers of the pertodontal ligantent were placed under tension when the force systems ware activated intruding this tooth. Since these fibers were stretched olliqualy, we can see that the crest would give the appearance of remodeling along similar lines. This is what the histologic sections indicate took place.

When the histologic sectiona were arst axamined there was come consternation conceming the apparent damage to the rook. Still when the sections were carefully appraised this tissue behavior was better understood.

Reitan (1947) reports intruaive forces cause hyalinization, this means, at least temporarily, that tissue vitality is reduced untl undermining resorption can change the environment auticlently. 
There was no evidence of hyalinization or undermining resorption seen in the sections of this experiment. The assumption can then We drawn from this olservation that a low magnitude continuous force can be designed which will catalyze bone reaction rather than reduce it, a phenomenon associated with hyalinization.

O'Donoghue, 1963, reports that "Ight" continous forces when used to tip a monkey premolar caused large areas of roo resorption and hyalinization. Yet when O'Donoghue's methods and materials are studied carefully there is no mention of the tact that when a tooth is tipped, primary areas of pressure are created at the marginal and apical areas of the alveolar bone. The magnitude of the force increases in each direction in the same increment for equal distances from the central axis of rotation. The alveolar crest is where the maximal magnitude of force cccurs coronally in one direction, while the maximal magnitude of force in the opposite direction is at the rook apex. The lack of considerations of the moments and couples created by the force sygtems places O'Donoghue's torce magnitudes far beyond the range of what might be considered "light forces". Unless all of the above factors are carefully assessed physically 
as well as histologically, it is erroneous to draw conclustons which are in efreet critical of the ugage $\alpha$ low mannitude continuous forces. In the atrletest sense of the word there were no controis used in this experiment. Although only the maxillary ceeth on one aide were subjected to a lorce system, yet as pointed out in the chapter on methods, the maxillary teeth on the opposite side in the same animals wexe banded. For the wam of a better term thege were called the "reference toeth". A group of teeth called reference teath were bandad so that they would be like the experimental teeth in all respocts except for the existence of the applance. This validates the Inference that any ditcrence in response between the two groups of teeth is attributable to the appliance. The presence of the bands had no real ertect on the physical measurements. This was vertilud In the histologic asseasment of the "weference teoth". These teath showed no histologic ditrerences from a normal environnent.

What noeds to be explained at the moment are the three large measurement seen in Table V. These atrexences were calculated hetweon the Initial moasurements of a fiven toch on an Individual animal and the final moasurements of that same toch. The 
diferences were then cested to determine whether any of the aprarent changes in tooch position were large enough to we due to something other than chance variation. The cccluso-gingival measurements of tooth on Monkey I appeared to have shown a real change. Tho buccal-lingual measurements on this ame tooth also appeared to have changed significantly.

At irst inspetion this finding seoms highy improbable. The question immediately comes to mind - how can reference teeth which are not directly infuenced by any orthodontic forces expertence changes in tooth positton large ancugh to be outalde the limits of exporimental error? After careful evamination of the ariginal data sheet from which the diterences published in Table VI were calculated, it was discovered that all of the above three apparent changes were derived from the same transier unit. That is, the Initial dimenstong taken fom the Wrat werence trangser unt o: Monkey l were responsible for the threc large diferences in Table V. The diverences taken from the remaining three trangtor units of Monkey I were all judged har below experimental orror. These apparent changes wers actually artifactual, since the ohservat ons rom one unit 
gave ribe to the large differences.

The question then comes to mind - what are the main sources of arror in this indirect tooh measuring method The materials used tor the impresalons of the monkey testh and the die stone from which the units are fabricated are two very important sources of error. Chapter III. "Methods and Materials", devotes an entire section to the dimengional stabulity of these materials. Anocher posalise source of exrot is in the orientation of the transter units into carrier units and the wax used to secure these ortented units in their carriers. The extensive invertigation of the reliability $\sigma^{t}$ this new method has developed proof that the method has good capabilities but that it needs to be refined and also extended to the making of measurements in other directions. 


\section{CHAPTER VI \\ SUMMARY AND CONCLUSIONS}

This study was designed to evaluate the biophyslcal inluence of a reciprocal vertical orthodontic force aystem applied to the maxillary poeterior teeth of rhesus monkeys. More specifically this horce syatem was intrusive on the second premolar and reciprocally extrusive on the firet premolar and molar teeth.

This research deals with the development and use of a method which precisely measures physical changes in tooth position in relation to two reference planes. The changes in tooth position were measured In two directions: ccclusomgingivally and bucco-lingually. The use of this method of measuring changes in toch position gives accurate physical dimensions for correlation with higtologic changes reaultiny from a given force ystem. Studies on the accuracy and precision of this method were conducted to learn whether the method was acceptable rom the standpoint of feasibility and reliability. Investigation of these aspects of the new method has devaloped proot that the method has potential application to uture atudies.

On the basis of the result of thi a experiment, the following 
conclusione can be drawn:

1. A new and unique physical method of measuring experimental tooth movement was used in this regearch and found to te rellable.

2. When light continuous depressing forces were applicd to the brackets of monkey premolaz teeth, it was ascortained by physical and hetologic methods of asessment that these tecth were intruded and tipped buccally.

3. When Iftht continuous imrusive forces are applied to premolax reath of monkeys, the histologic sectiond aw areas of comentum and domein tosorption at the aplos and roce irifurcation. It was also aberved that alvoolar crest bane regortyon and difeet bone renorption of the cribriform plate took place. Buccal-Lingul topung was also obertus in the transverse hitologie ections. This is a comptctely new approach to an assessment of the teftect of discrete lores yetems.

4. Teeth of monkey extruded orthodontically agaings the forces of oclustan with Ifgit continuous forces did not 
demonstrate any measurable bucco-lingual or occlusogincival changes. This minht be anticipated in view of the forces of occlusion. The occlusal orces in quastion tended to intrude those teeth which were used as anchor units for the intruaion of the aecond premolars.

5. The hiatologic picture of the anchor teeth gives the Impression these teeth were "iggling". The jigling behavior was identined by cemsentum resorption and also alveolar crest resorption in interradicular crest areas of the roo trifurcation. In addition to this further evidence of "jiggling" was seen in the increased width of the periodontal space in both the transverse and sagittal histologic sections.

6. A point of real significance for iture studies to consider is that if any comparison is to be drawn from animal studien concerning the tehavior of force systems, the magnitudes of forces and couplea mployed must be chosen to produce roo pressures lyng within physidogic limits. Failure to calculate the pressures for the emall 
roote will invariably produce er ronecus interpretation o results. 


\section{BIBLIOGRAPHY}

Aisenver, $M$. The tisswe and changes involved in orthodontic toch

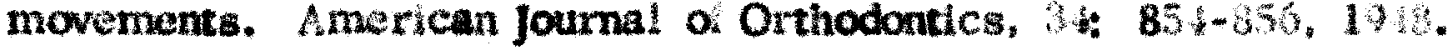

Alexander, R.H. Rationale and application of the Jaratrak light wire technique in orthodontics. Now York Journal of Dentistry, 33: 149. 1963.

Anderson, D. J. Tocth movement in exporimental malocclusion. Archives of Oral Biology, 7: 7-15, 1962.

Arkin, H. and Colton, R. Tables for Statisticlans, Barnes and Noble, Inc. . New York, 1950.

Bien, 5. M. Analysis of the components of lorce used to move tecth. European Orthodontic Sociaty Transactions, 33: 70-7\%, 1957.

Breitner, C. Bone changes resulting rrom experimental orthodontic treatment. American Journal of Orthodontics and Oral Surgery. 26: $521-5+7,1940$

Burstone, C. J., Baldwin, J. J., and Lawless, D. T. Application of continuous sorces to orthodontics. Angle Orthodontiat, 31: 1-14. 1961.

Cohen, B. J. The carly history of animal experimentation and animal care. Animal Care Panal, 9:39-45, $145 \%$.

Cushing, C. R. Obervations of pressure phenomena on bone in vivo. American Journal of Othodontics, 17: 150-151, 1961 .

Diamond, H. D. Practical application of Itght wire technique. American Journal of Orthodontics. s6: 650-669, 1962.

Fisher, R. A. The Dusign o Experiments. Third Edition. Oliver and Boyd Ltd., London, England. 
Gillngs, Barrie, et al. Apparatus for cutting thin webealciffed section of teeth. Journal of Dental Research, 387 702, $195 \%$.

Haack, D. C. The seience of mechanics and Its Imporance to analyois and research in the nteld of orthodontiea. American Journal of Orthodontics, 49. $330-344,1963$.

Hartman, C. and Strauts, W. The Anatomy of the Rhesus Monkey. The Williams and wilkings Company, Baltimore, 1933,

Meraberg, B. L. Bone changes Incident to orthodentic tow movement. The Journal of the American Dental Association, 19, 1777-1788, 1932 .

Hamley, S. The elinical significance of tissue changes iveldental to tocth movement. American journal of Orthodontics, il: $1-26$, 195 .

Hopewell-Smith, A. A process of osteolystm and odontolyots or socalled "Absorption" of calctfled tisatue. A new and original investigation. Dental Cosmos, 72: 323-345, 1930.

Huctner, R. J. Experimental histological etudy of the effeets of orthodontic tooth movenent on the Nacaca Rhesus monkey. American Journal of Orthodentics, 46, 481-514, 1960.

Huettner, R. J. and Whitman, C. L. Tissus changes occurring In the Macaque Rheaus monkey during orthodontic movement. American Journal of Crthodontics, 46, 481-513, 1958.

Hurme, V. O. Estimation of monkey age by dental formula. Annals of New York Acadamy of Science, 85; 735-992, 1960.

Irish, R. E. Conscious constructive application of pressure. International Journal of Orthodontica, Oral Surgery, and Radiolosy, 13. 528-539, 1927 . 
James, w. W. The jaws and Teath of Primates. Pitman Medical Pullishing Co., Ltd. London, 1960.

Jaratak, J. R. and Tlusell, J. Tochnique and Treatment with the Light Wire Appliances. The C. V. Mosby Co., St. Louis, 1963.

Johns, E. E. Study of the forces inherent in orthodontle appliances and the setection of joices or tocth movement. Journal of The Canadian Dental Assoclation, 11: $323-436,1953$.

Lindquist, J. T. Indiree band technic. Angle Orthodontiat, 29: $114-122,1959$.

Myars, H. I. and Wyatt, W. P. Some histopatholic changes in the hamoter as the result of a continuously acting orthodoncic appliance. Journal of Dental Research, 40, 846-356, 1961.

O'Donoghus, D. J. Comparative Responses of Paradental Tissuss to Continuous and Intermittent Application of Forces. Unpulis shed Masters Thesis. University of Illinois, 1953.

Oppenhaim, A. Blologic orthodoutic therapy and reality. International Journal of Orthodontics and Dentiatry for ChIIdren, 19, 1201-1213, 20. 18-24, 137-146, 250-258, 331-336, $661-166,639-644,759-769$, $961-968,1072-1076,1176-1181,1933$ and 1934.

Biologic orthodontic therapy and realizy. Angle Orthodontist, 6. $5-3 \%, 69-116,154,133,1936$.

Human tissue rapponse to orthodontic intervention of short and long duratioa. American Journal of Orthodontics and Oral surgery. $23: 299,19 \pm 2$.

Ortan, B. Bioloyic proilems in orthodontia. The Journal of the American Dental Association, 23, 1819-1270, 1936.

Parfitt, G. J. Measuremant of Intruaion of the upper incisor tecth with rorces bolow 1,000 grams. Journal of Dental Research, 35: 651 , 1959. 
Reltan, K. The Initial vissue reaction incldent to orthodontic tocth movement as related to the infuence of function. Acta Odonto. Scandinav. (supp. 6h), 1951.

Thase changos ollowing experimental tooth movement as related to the time ractor, Dental Record, 73, 559, 1953.

Retraction o upper canines ater removal of arat premolar: Relation to tistue reaction. Furop, Ortho, Sce. Tr., 34 $172-176,197-210,1058$.

Tasue behavior during orthodoatic tooth movenent. American Journal of Orthodontics. T6. $381-839,1960$.

Nosue reaction as relatod to the age actor. Dontal Record, 74271,1954

Etrects of force magnitude and direction of toot movement on alveolar hone. Angle Orthodoutlat, 34:24-255, 1964.

Rich, S. and Cohn, B, J. A regtraint unit for large monkeys. Animal Care Panal, 12, $133-116,1962$.

Richmond, J. E. An appliance analysis with measured pressure. International Journal or Orthodenties and Dundstry for Children, 29* $898-908,1933$.

Sandertan, 1. T. The Motkey Kingdom. Chilton Company, New York, 1023.

Sandstedt, C. Einge Beitrage sur Theorle der Zam Rogulierung, Nordlak. Tand. Tdak. no. 4, 190", no. 1, 1905.

Schwar., A. M. Tissue changes Incidental to orthodontle tooch movement. International journal of Orthodontics and Oral Surgery, 1/: 331-351, 1932. 
Sicher, H. and Wainmann, J. Bone growth and physiologlc tooth movement. International Journal of Orthodontion, 23, 331-351, 194.

Sicher, H. Changiny concepta of supporting dontal struatures. Oral Surgary, Oral Medicine, and Oral Pahology, 12 3135, 1959.

Storey, E. and Smith, h. The importance of the design of cuapd retraction spirings. Australian fournal of Dintistry, $36,291-30 \div, 1952$.

Force in orthodontics and its relation to tocth mowement. Australian Journal of Dentiatry, 5/5: 11-16, 1952.

Storey, E. Bone changes associated with tooch movemant. Australian Jounual of Dentistry, $57,57,195 \%$.

Stuteville, O. H. A sumarnary repiew of tisave changer incident to tooth movement. Angte Orthodontist, is: 1, 193.

Tully, w. J. Orthoductic treatmant and patiodontal tissues. Dantal Practitioner and Dental Record, 9 194-200, 1959.

Wetmann, J. P. and Sicher, Hone and Bonot. The C. V. Mosby Co., St. Louls, 1985 .

Wentz, F. M., Jaralak, J. R., end Orian, B. Experimental ceclusal trauma imitating cuspal interistences. Journal of Periodontium, 2\%, 117-127, 1953.

Wescott, R. and Rateroin. M. Important actors contributing to reduction in mortality in a montey colony. Laboratory Animal Care, 13, $744-43,1965$. 


\section{APPROVAL SHEET}

The thesis sulumitted ty Dr. Gerald J. Jefiry has been read and approved hy mombers of the Demartmonts of Anatomy and Oral Btology.

The final copies have been axamined sy the director o the thesis and the signature which appears below verifres the fact that any necessary changes have been incorporated, and that the thesis is now given final approval with reference to content, form, and mechanical accuracy.

The thesis is theretore accepted in partial fultillment of the requirements for the Degree of Master of Sclenco.

$\frac{210 y / 9-65}{\text { DATE }}$

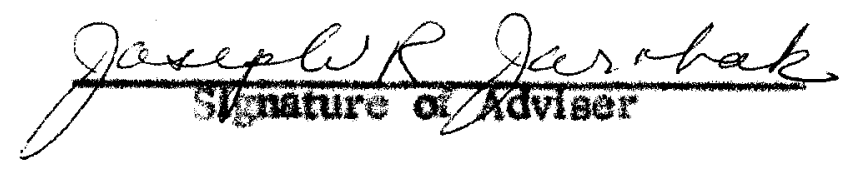

